\title{
Thermal Plasma Treatment of Medical Waste
}

\author{
Xiaowei Cai ${ }^{1} \cdot$ Changming $\mathrm{Du}^{1,2}$
}

Received: 17 March 2020 / Accepted: 4 August 2020 / Published online: 7 September 2020

(c) Springer Science+Business Media, LLC, part of Springer Nature 2020

\begin{abstract}
The harmless treatments of medical waste have significantly drawn people's attention owing to their risks to health-care staff, the public, and the environment. The traditional thermal technology for processing medical waste may cause indispensable secondary pollution such as dioxin, furan, and heavy metals, and infectious materials that may remain in the solid residual. Thermal plasma technologies offer advantages of effectively treating medical waste due to its high temperature and energy density, lower pollutant emissions, rapid start-up and shut-down, and smaller size of the installation. These benefits play roles in the treatment of medical waste on-site or off-site, especially when somewhere encounters an abnormally sharp increase in medical waste. This paper mainly introduces the typical thermal plasma processes of medical waste and its central component, plasma furnace. Meanwhile, how process parameters influence the formed gaseous and solid products, the performances of mass and volume reduction, pathogen destruction, and energy recovery, are discussed in detail. Finally, the mechanism of the thermal plasma process is also analyzed.
\end{abstract}

Keywords Thermal plasma $\cdot$ Medical waste $\cdot$ Gasification $\cdot$ Pyrolysis $\cdot$ Vitrification

\section{Introduction}

According to the World Health Organization (WHO), health-care waste includes all the waste generated within health-care facilities, research centers, and laboratories related to medical procedures [1]. Generally, the term medical waste is used interchangeably with the term health-care waste [2]. Meanwhile, the variations in its definitions are used worldwide [3]. In this paper, medical waste refers to any hazardous health-care waste which is potentially infectious, pathological, pharmaceutical, cytotoxic, chemical and radioactive wastes, and any non-hazardous health-care waste.

Changming Du

duchm@mail.sysu.edu.cn

Xiaowei Cai

caixw5@mail2.sysu.edu.cn

1 School of Environmental Science and Engineering, Sun Yat-sen University, Guangzhou 510006, Guangdong, China

2 Taizhou Institute of Zhejiang University, Taizhou 317000, Zhejiang, China 
Global concern over the treatment and disposal of medical waste is not fully addressed. Since the generation of medical waste from the healthcare industry has rapidly increased, which is faster than the infrastructure to deal with it. High-income countries generate on average up to $0.5 \mathrm{~kg}$ of hazardous waste per hospital bed per day; while low-income countries generate on average $0.2 \mathrm{~kg}$. Moreover, these hazardous medical waste is about $15 \%$ of the total amount of waste [4]. Another problem occurs during a disease outbreak. Rapidly increased medical waste brings big challenges to their treatment and disposal. For example, recent COVID-19 outbreak which has been characterized as a pandemic causes the increase of generation of medical waste during care of COVID-19 patients and the situation may be much more serious as the outbreak spreads. If medical waste is not properly managed, it will pose a great threat to the environment and humans due to its toxicity and infectious nature.

The composition of medical waste varies widely and is changeable as the development of the health-care industry. It may contain only inorganic material or can consist of very humid and organic material. This leads to a calorific value of medical waste that can range from 2 to $40 \mathrm{MJ} / \mathrm{kg}$ [5]. The plastics content of the medical waste stream has grown from 10 to $30 \%$ and could be more in the future $[6,7]$. Therefore, the increasing heating value of medical waste makes it a promising prospect for energy utilization.

Hazardous medical waste is regulated with increasingly stringent regulations in recent years. There are several methods available for medical waste treatment, such as microwaving, autoclaving, thermal treatment, etc. Thermal treatment is regarded as the most radical and universal method. Incineration of medical waste results in stack gases, bottom ash, and fly ash releases [8-10]. The stack gases may contain PCDD/Fs, PAHs, inorganic acidic gases, and metals. What is more, medical waste generally contains higher plastic content compared with municipal solid waste, thus its combustion may lead to more formation of PCDD/Fs [11]. On the other hand, fly ash and bottom ash are also classified into hazardous wastes that face the difficulty of subsequent processing. Pyrolysis of medical waste refers to the decomposition of organic components in the absence of oxygen, which produces char, oil/wax, and combustible gases $[12,13]$. Gasification generally follows three steps: preheating and dry, pyrolysis and char gasification, and char oxidation [14]. Both of them have significant benefits in terms of low operation temperature, improved pollution control, and generation of value-added products. The advantages and disadvantages of these thermal methods are shown in Table 1. For thermal plasma process, reducing energy consumption and achieving energy and material recovery are available ways to reduce treatment cost and increase process efficiency, which make it potentially successful to commercialization [15]. In recent decades, a huge movement toward improving the service life of plasma torch has been made to overcome another difficulty that electrodes suffer from chemical and electrical erosions. The continuous operation of plasma torch can reach several $1000 \mathrm{~h}$ in some cases at present [16]. The actual lifetime depends on the type of torch and waste stream, the type of plasma gas, the power of the system, etc. Generally, the extension of operating life is achieved by reducing arc current, selecting optimal electrode material and its structure, moving arc attachment by the forces (gas, magnetic and aeromagnetic), using shielding gas, etc. [16-21]. Meanwhile, thermal plasma torch of high powers may still undergo a higher erosion rate as high current is the most common design to increase the power. The high-voltage plasma system and multi-torch plasma reactor are therefore developed. In a word, the disadvantages of the thermal plasma method are gradually overcome with the developer's efforts and the application will be more economically feasible in the future.

Faced with these problems, thermal plasma technology for treat solid wastes is recognized worldwide as being highly efficient and it has been used for the elimination or 


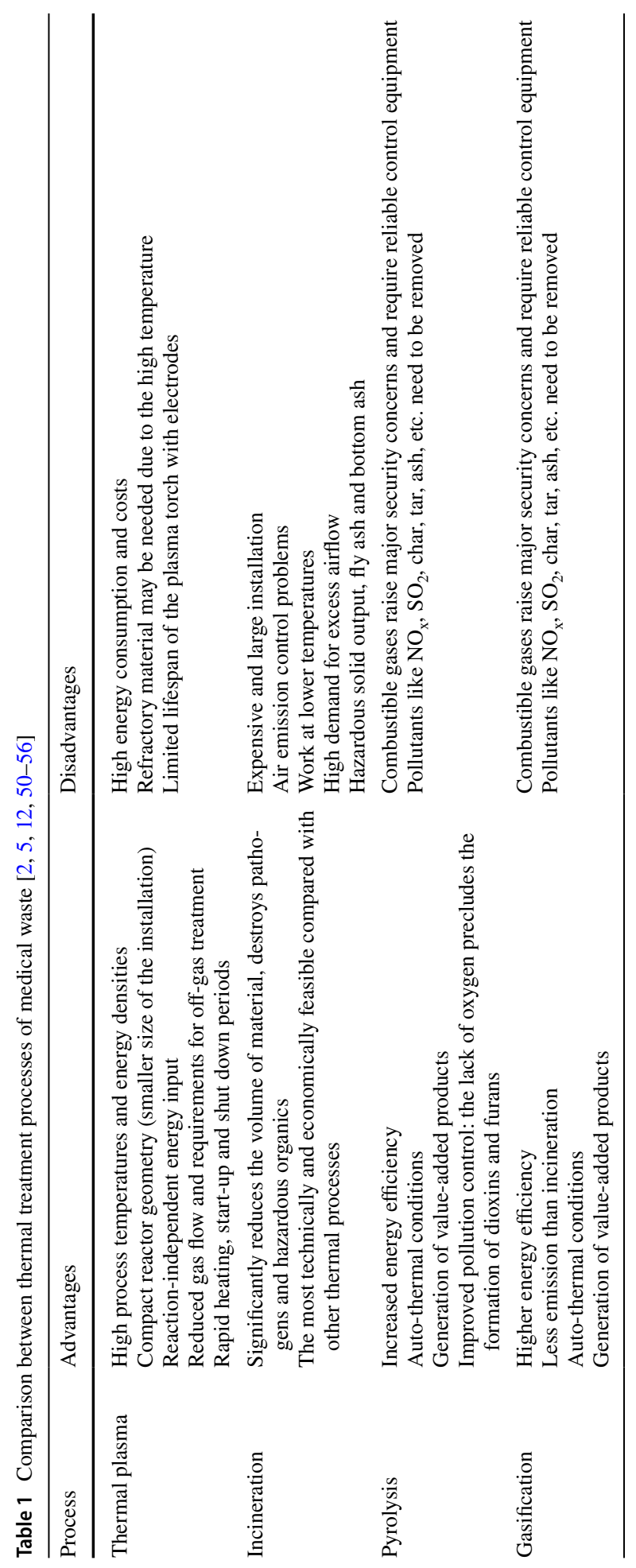


transformation of different types of waste including plastics waste [22, 23], waste tires [24-26], biomass [27-29], municipal solid waste [15, 30, 31], electronic waste [32-34], fly and bottom ash [35-39], municipal and industrial sludge [40-44]. Plasma methods are not only used for the production of fuel gas but also appear to be high potential to produce glass-like slag that can be utilized or from which to recover metals [45, 46]. Therefore, it may be a promising alternative to solve the problems of medical waste. On-site treatment is a good way to treat and dispose of medical waste especially in emergencies. Some researchers suggest installing temporary incinerators may be an effective solution for managing the tremendous increase in medical waste [47]. However, stringent regulations on air pollutant emissions of on-site incinerators and the large installation are the biggest challenges $[48,49]$. Thermal plasma technology not only offers the advantages of high process temperature, reducing the requirements for off-gas treatment but also allows a smaller size of the installation. Therefore, it is a promising alternative for the on-site and off-site treatment of medical waste.

In this way, the main objective of this paper is to compare the existing thermal plasma treatment processes of medical waste. We reviewed numerous pieces of literature and focused on four types of basic thermal plasma treatment processes and their plasma reactor configurations. Meanwhile, the paper also discussed how different technical parameters influence the yield of gaseous and solid products, the effects on mass and volume reduction, the performance of destroying pathogens, and the potential to recover energy. Moreover, the mechanism of thermal plasma treatment of medical waste is also discussed. Therefore, this review paper gives a comprehensive insight into the safe disposal of medical waste with this promising technology.

\section{Treatment Processes and Plasma Reactor Configurations}

\section{Typical Thermal Plasma Processes for Treating Medical Waste}

Table 2 shows the comparisons among some thermal plasma treatment facilities and lab-scale processes for medical waste around the world. Generally speaking, most existing thermal plasma treatment facilities treat municipal solid waste, incineration ash, and other hazardous wastes. The high feedstock adaptability of the thermal plasma technology implies that these plants also possibly have the ability to treat medical waste (these plants are not listed in Table 2). This can be demonstrated by the multiple waste streams including medical waste in some plants. Meanwhile, studies about thermal plasma treatment of medical waste are fewer than that of other types of waste (e.g. MSW and fly ash). In the existing studies, the process can be categorized into plasma combustion, plasma pyrolysis, plasma gasification, and plasma vitrification. Most processes focused on not only medical waste but also other types of hazardous wastes. Currently, plasma gasification with a DC power supply has the highest commercialization level. Although a variety of investigations have focused on the application of the AC plasma torch, most of them are not commercialized.

\section{Plasma Combustion Process}

Incineration is the common safe disposal of medical waste in developed counties, whereby its advantage of reducing waste volume and weight and ensuring sterilization at high temperatures [11]. Plasma combustion (plasma oxidation) is a developed 


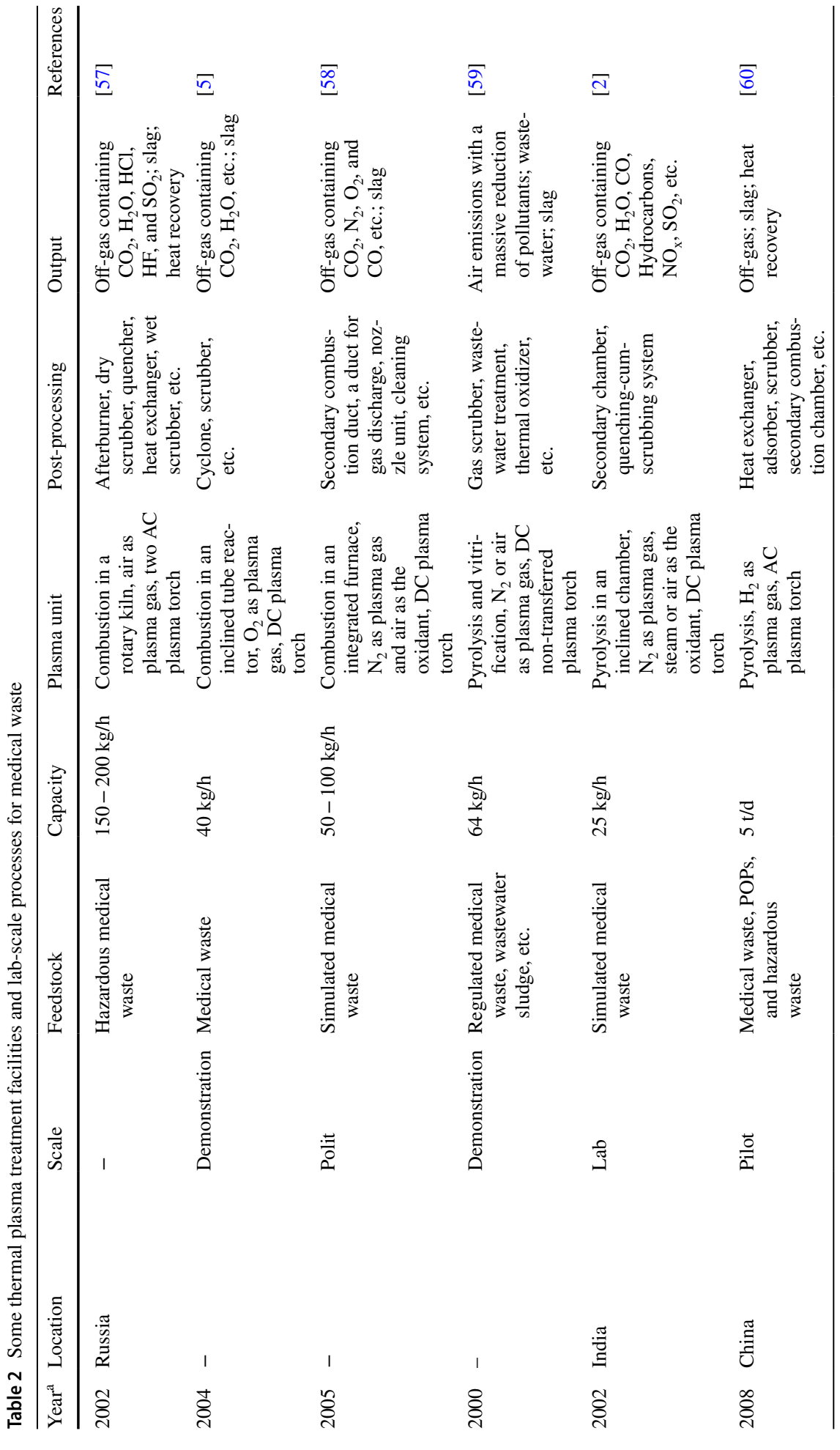




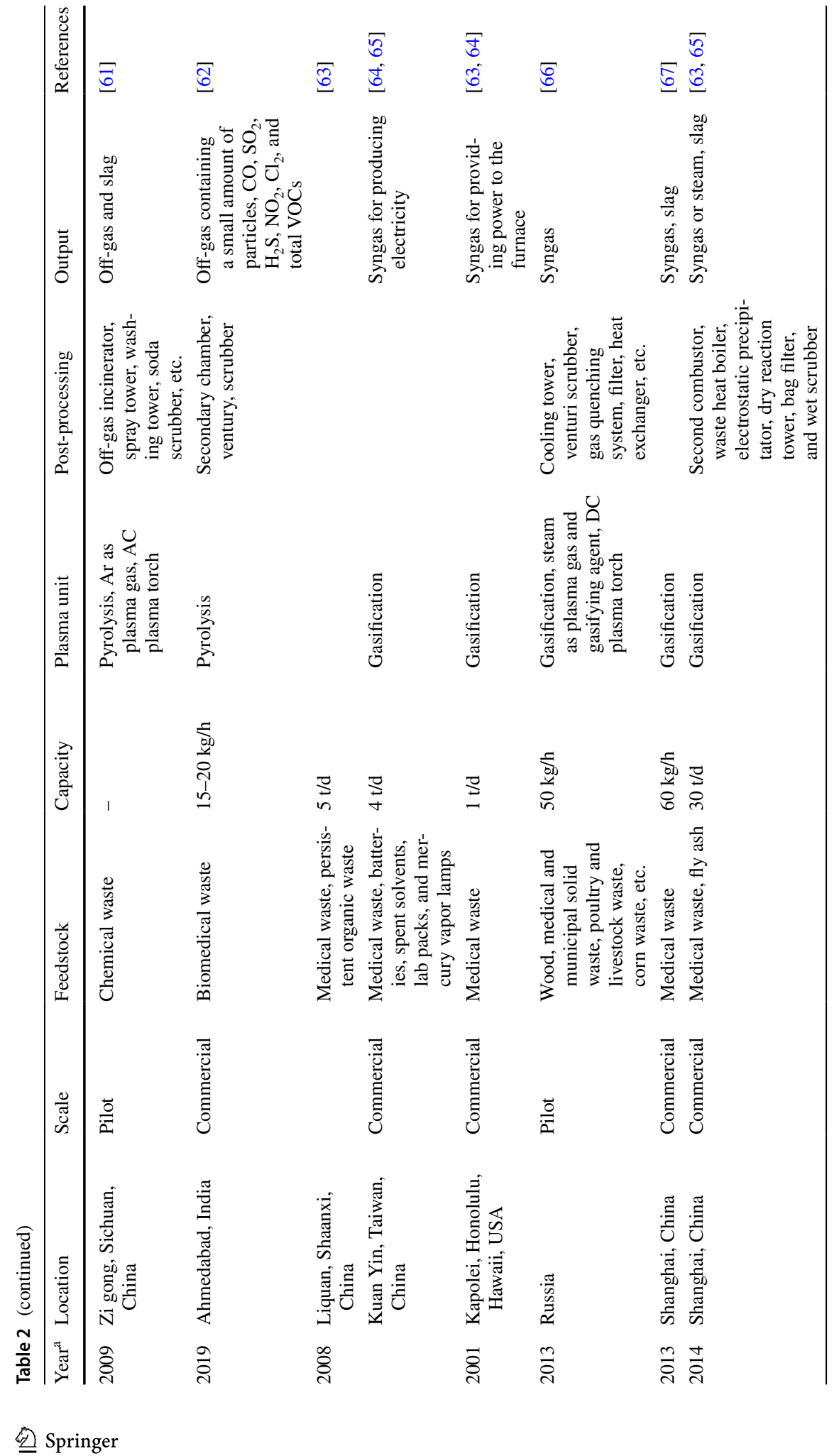




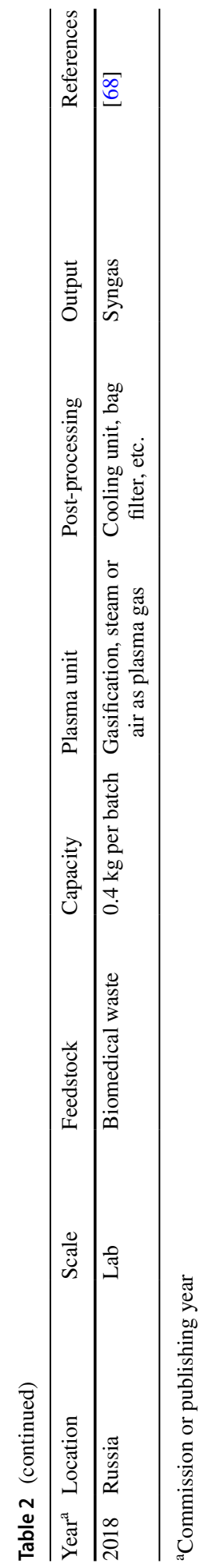


incineration process in which plasma torch is used as a heat source with excess oxygen. This process is widely investigated in internal combustion engines and spark ignition systems [69-72]. It has been claimed that the plasma provides various active species to enhance combustion and activate fuel oxidation pathways, especially at low and intermediate temperatures. This effect of plasma catalysis not only enhances combustion at a lower temperature but also reduces the air requirement. Generally, the factor of air excess in plasma furnace is approximately 1.0-1.2 in the plasma treatment of waste [57], lower than that of typical incinerator (1.6-2.0) [73]. A similar low factor was also reported in a plasma oxidation process of sludge (the value is 1.2-1.25) [74, 75]. This means gases and dust emissions and heat dilution can be reduced. In practice, there are several representative plasma combustion investigations described below. Unlike plasma pyrolysis and gasification, combustible components are not the major component of the off-gas after the plasma combustion furnace. Hence the addition of an afterburner relies on the quality of off-gas and input requirement of the subsequent units. In the case conducted by Fiedler et al. [5], afterburner was not provided probably due to the use of $\mathrm{O}_{2}$ and the re-processing of the process gases. Rutberg et al. [57] reported a process used for plasma-chemical disinfection of hazardous medical waste with a capacity of $150-200 \mathrm{~kg} / \mathrm{h}$, as shown in Fig. 1. The first stage combustion employs a rotary kiln with delivering three types of air into the furnace, maintaining a temperature of $1000-1200{ }^{\circ} \mathrm{C}$ by two AC plasma torches. Hot air from plasma generators, additional air and water are for control of temperature and quality of waste plasma combustion. For air plasma, a significant amount of nitrogen oxide forms at high temperatures. At an above-layer part of the furnace, the flue components burn out before coke combustions proceed with the formation of $\mathrm{CO}$ and $\mathrm{CO}_{2}$. When oxygen is deficient and when water vapors are present, the process of combustion occurs with the formation of significant amounts of $\mathrm{CO}$ and $\mathrm{H}_{2}$, which are good reducers of nitrogen oxides. Meanwhile, a small amount of soot, chloride, fluoride, and sulfide may be formed depending on the composition of medical waste. After the rotary kiln, flue gases move into the afterburner (one plasma generator is mounted), where they are transformed into $\mathrm{CO}_{2}, \mathrm{H}_{2} \mathrm{O}, \mathrm{HCl}, \mathrm{HF}$, and $\mathrm{SO}_{2}$ with additional air and water at a temperature range of $1200-1400{ }^{\circ} \mathrm{C}$ and a residence time of $\sim 2 \mathrm{~s}$. Following this treatment, flue gases are presented into the dry scrubber, sharply cooling to temperatures of $900-950{ }^{\circ} \mathrm{C}$, which avoids free $\mathrm{Cl}$ formation and reduces nitrogen oxide via an injection of water urea solution. Afterward, the temperature of flue gas decrease to $300-320{ }^{\circ} \mathrm{C}$ passing through quencher and heat exchanger. A wet method of flue gas cleaning, demister, and arosol filter is chosen to remove fly ash,

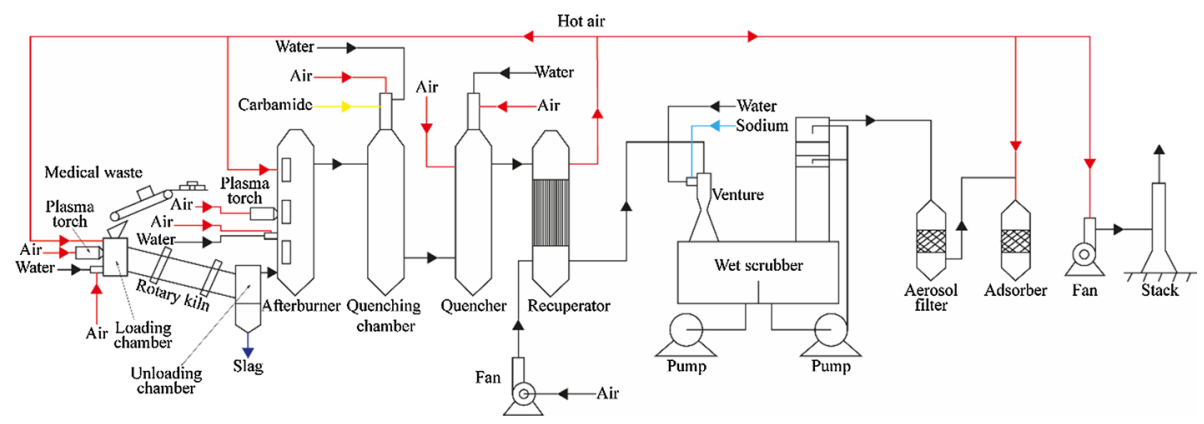

Fig. 1 Schematic diagram of medical-waste treatment by the plasma-chemical method [57] 
residual soot, heavy metals, and acid gases. At last, flue gases are diluted with heated air at $120-150{ }^{\circ} \mathrm{C}$ and ejected into the atmosphere through the stack.

A demonstration plant for the thermal destruction of medical waste using $50 \mathrm{~kW} \mathrm{DC}$ plasma torches has been developed [5]. As presented in Fig. 2, the main component of the system is an inclined tube reactor, with a scrubber, a re-cooling system, and a compressor. A screw conveyor is used to transport the medical waste from the reservoir with a maximum mass flux of $40 \mathrm{~kg} / \mathrm{h}$. Once it reaches the mixing chamber, the plasma jet produced from the plasma torch transfers heat to the waste, converting it to $\mathrm{CO}_{2}$ and $\mathrm{H}_{2} \mathrm{O}$, and melting it in the presence of oxygen. This happens at temperatures between 2000 and $2500{ }^{\circ} \mathrm{C}$. The process gases go round in a back-end reconditioning loop. It means after the conditioning stages (scrubber, water re-cooling system, compressor), the gas passes through the plasma torches again.

Another pilot-industrial experiment of medical waste using plasma furnace is shown in Fig. 3 [58]. The whole process is almost an integrated furnace, which consists of a combustion chamber, a second combustion duct, a duct for gas discharge, a nozzle unit for injecting water into the effluent gases, and a cleaning system. The medical waste is packing and drops from a charging opening in the center of the vertical shaft, falling into the bath where thermal destruction occurs. Two main plasma torches are installed in the chamber, one is with a power of $40-45 \mathrm{~kW}$, an airflow rate of $4-6 \mathrm{~g} / \mathrm{s}$, and a plasma jet temperature of $3000-4000 \mathrm{~K}$; another is with a power of $65-85 \mathrm{~kW}$, an airflow rate of 7-9 g/s, and a jet temperature of 2500-4000 K. The jet of the main plasma torch attacks the bottom of the bath at an angle of $45^{\circ}$. At high temperatures, the organic components of wastes are decomposed into volatile matters and then combusted. While the non-organic components are melted through a slot in the brick-work at the bottom and into a slag receiver. The gas flow from the combustion shaft enters the second combustion duct where horizontally positions a plasma torch with $15 \mathrm{~kW}$. The air is used to cool the furnace jacket. After the second combustion duct, the gas flows out at a right angle downward and passes through a gas discharge duct for cooling the gas to about $150-200{ }^{\circ} \mathrm{C}$. The steam gas flow is further discharged through a fan immediately into the atmosphere, or it is passed through the wet gas cleaning system and then into the atmosphere.

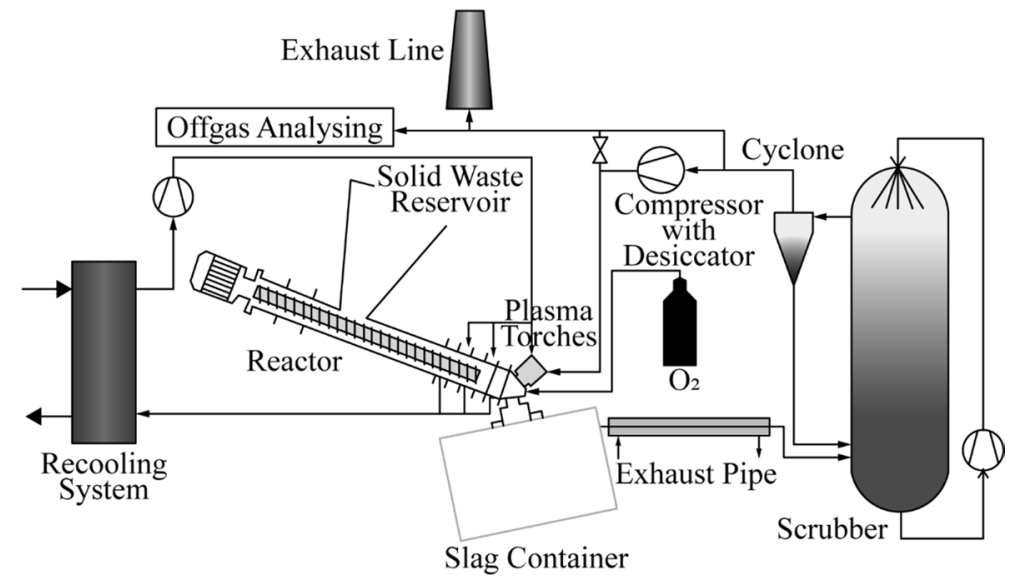

Fig. 2 Demonstration plant for medical waste disposal using DC thermal plasma process [5] 


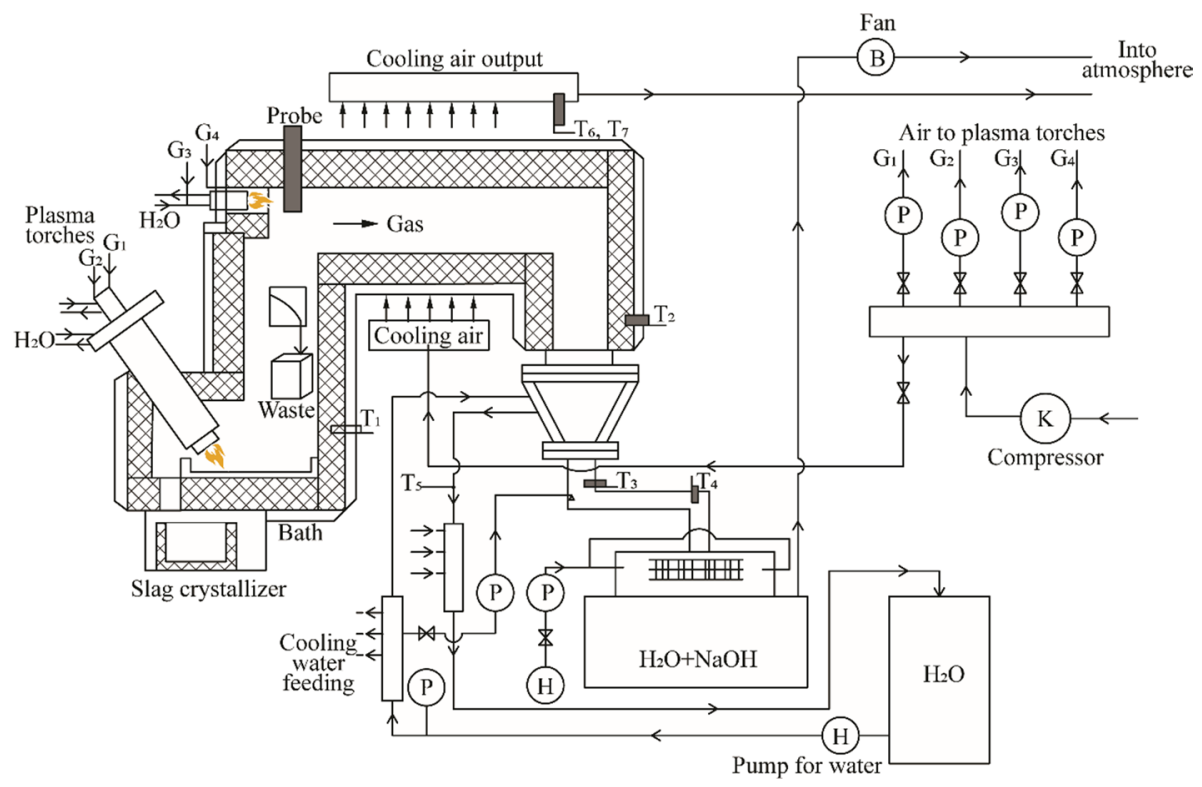

Fig. 3 A pilot plasma process for treating medical waste [58]

\section{Plasma Pyrolysis Process}

Pyrolysis refers to a process in which organic matter is thermally decomposed in the absence of oxygen to produce smaller molecules. More specifically for plasma pyrolysis, the products are only composed of $\mathrm{CO}, \mathrm{H}_{2}$, and a small amount of higher hydrocarbons [76]. For medical waste, these organic fractions are chiefly plastics, paper, and cloth items. There are three main products that are found after pyrolysis including fuel gas, char, and oil. Generally, not only waste type but also pyrolysis process type play significant roles in the variation of these pyrolysis products. On the basis of heating rate, pyrolysis process types can be classified into slow pyrolysis, fast pyrolysis, and flash pyrolysis [77]. These processes are developed with various desirable goals, mainly for adjusting the final products. Generally, slow pyrolysis is employed to focus on the maximum of solid product yield, whereas fast and flash pyrolysis seek for the yield of liquid bio-oil product [78]. However, these products may be impure and hard to separate them. Therefore, catalytic pyrolysis and plasma pyrolysis have caused more considerable interest in recent years. Catalytic pyrolysis of plastic waste is used for overcoming the problems of the low quality of liquid oil, impure fuel gas, and high energy consumption [79]. The introduction of catalysts (mainly FCC, zeolites, and silica-alumina) was claimed to increase residence time and temperature, enhance the decomposition of hydrocarbons, improve the yield of gas and upgrade the quality of liquid oil $[79,80]$. For plasma pyrolysis, no liquid products are generated according to Huang et al.'s review [81], which is an advantage over conventional pyrolysis. This may be caused by the relatively high temperature and plasma species in a pyrolysis process. Compared with catalytic pyrolysis, plasma pyrolysis has greater adaptability to feedstock type and higher reaction temperature, thus leading to very detailed organic decomposition [82]. In summary, various pyrolysis processes have the extreme flexibility to optimize process parameters for desired product yield. A brief comparison of 
several types of pyrolysis process is presented in Table 3. In plasma pyrolysis of medical waste, pyrolysis gas is normally burned in the secondary chamber with some excess quantity of air to control air emissions. As the project expands to a larger scale, the economical efficiency and the modification/addition of requirements have to be considered. For instance, the combustible gas can be utilized to recover heat or electricity; the treatment of wastewater from the gas cleaning subsystem need to consider; the delivery of waste should adapt to the feedstock characteristics.

The plasma pyrolysis therefore can be defined as a process using thermal plasma as a heat source in which a carbonaceous solid is decomposed with limited amounts of oxygen at very high temperatures. An inert gas like argon and nitrogen or $\mathrm{H}_{2}$ is generally used to generate plasma in this process. Typical medical waste includes paper and cloth items, plastic, glassware, and fluid. An experimental test of simulated medical waste was carried out by Nema et al. [2]. As is described in Fig. 4, the system consists primarily of the plasma torch, power supply, gas injection system, primary reaction chamber, secondary reaction chamber, quenching-system-cum-scrubber, induced draft fan, and chimney. The distinguishing feature of the process is that two chambers are installed. The plasma torch composed of a water-cooled tungsten tip with an auxiliary copper anode surrounding it works with a $50 \mathrm{~kW} \mathrm{DC} \mathrm{power} \mathrm{supply.} \mathrm{N}_{2}$ gas is injected through the torch to produce a plasma jet. In the primary chamber, feeding medical waste is decomposed at high temperatures (approximately $900{ }^{\circ} \mathrm{C}$ ), generating low molecular weight gases. Following this subsystem, the produced pyrolytic gases, $\mathrm{N}_{2}, \mathrm{H}_{2}, \mathrm{CO}, \mathrm{CH}_{4}, \mathrm{CO}_{2}, \mathrm{C}_{2}-\mathrm{C}_{5}$, are introduced into the second chamber. These gases are burnt at the temperature of $1050 \pm 50{ }^{\circ} \mathrm{C}$ with some excess quantity of air and they are converted into $\mathrm{CO}_{2}$ and $\mathrm{H}_{2} \mathrm{O}$. After combustion, the hot gases passes through a quencher-cum-scrubber, where the gases are quenched in alkaline water $(12 \mathrm{pH})$ which brings down their temperature to $80{ }^{\circ} \mathrm{C}$ or less. The quenching restricts recombination reactions which otherwise produce toxic compounds. The residual gases are released with the help of an induced draft fan and chimney.

DC plasma torch is widely used in the thermal plasma treatment of solid waste, but some studies also applied AC plasma torch to treat medical waste. Sheng et al. described a pilot process treat medical waste using a $250 \mathrm{~kW}$ three-phase AC plasma pyrolysis system, which located in Xiangyang, Shaanxi, China [60]. The plasma furnace is presented in Fig. 5. Before the furnace, the feed-in subsystem is designed to prevent air from entering. That is, the furnace charging door is not open until the hopper is sealed. $\mathrm{H}_{2}$ is introduced to the furnace in which the negative atmosphere avoids the plasma gas from leaking. Inside the pyrolytic furnace, $\mathrm{H}_{2}$ plasma is generated to crack material into $\mathrm{H}_{2}, \mathrm{CH}_{4}, \mathrm{CO}$, and other small molecular combustible gas. Additives such as $\mathrm{CaO}$ and $\mathrm{SiO}_{2}$ are mixed with the melted wastes to enhance the vitrification process. The post-processing is similar to other pyrolysis processes, mainly including the combustion and cleaning of off-gas. The advantages of this process include preventing the energy loss from $\mathrm{AC}$ to $\mathrm{DC}$, minimization of the generation of air pollutants in a reductive environment, the enhancement of metals solidification, and mobile-type system. Medical waste also refers to much overdue chemical waste mixed with/without other types of waste. An AC plasma pyrolysis process was developed to treat chemical waste, as shown in Fig. 6 [61]. The system consists of shredding, mixing, and feeding subsystems, a plasma reactor system, an off-gas burning subsystem, an acid-gas recovery subsystem, and a scrubbing subsystem. Before entering the plasma reactor, the chemical waste is mixed with some additives, such as $\mathrm{CaO}, \mathrm{SiO}_{2}$, $\mathrm{Fe}$, for better formation of the vitrified slag. In the plasma reactor, the waste mixture is heated up to melt state in enough residence time at a temperature of above $1800 \mathrm{~K}$. The molten slag is quickly quenched to form an amorphous glassy structure, while hazardous 


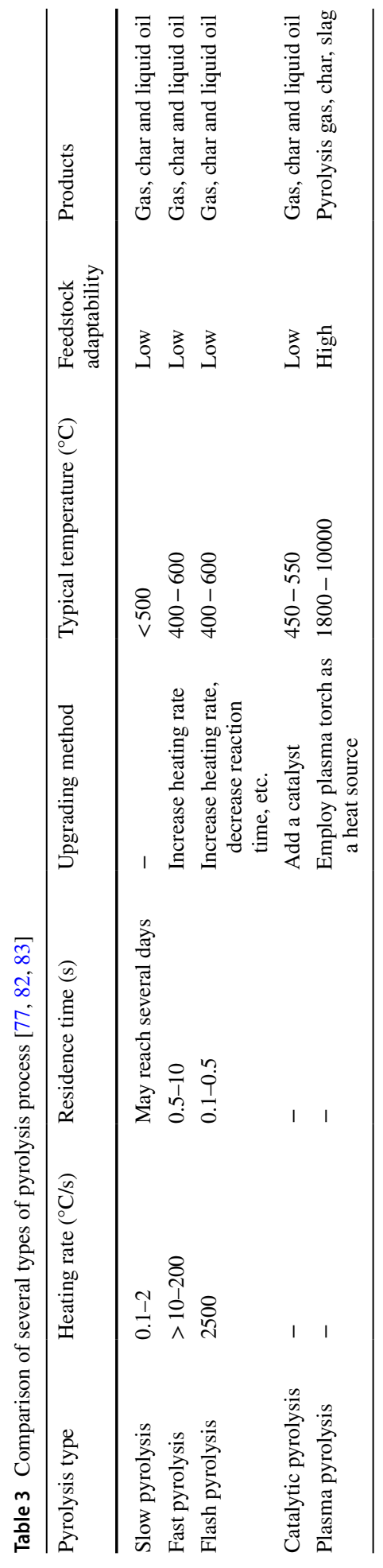




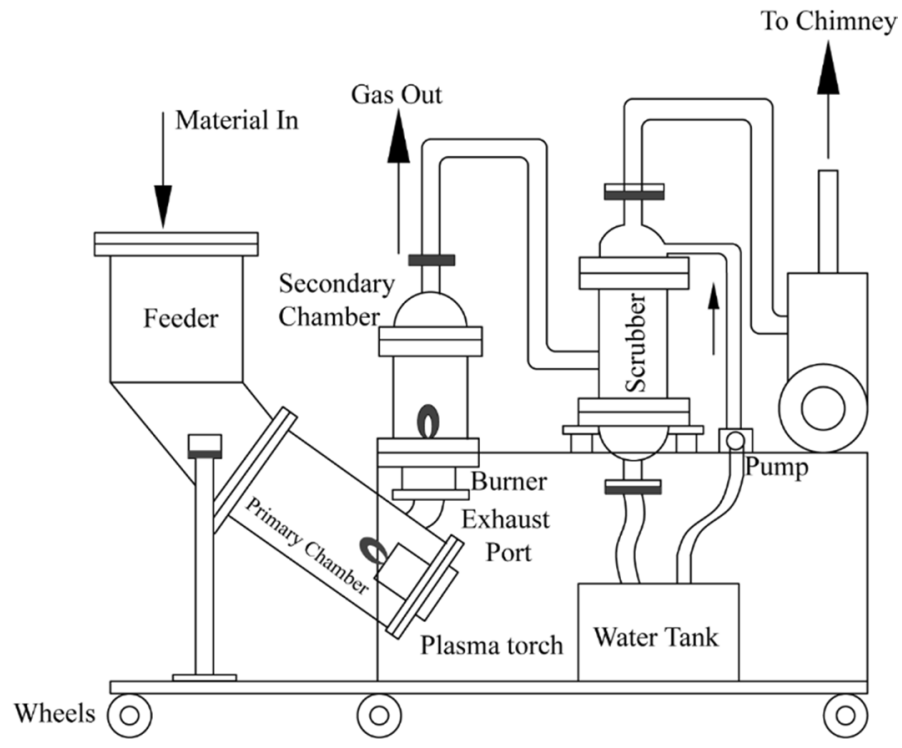

Fig. 4 Schematic diagram of plasma pyrolysis system for treating simulated medical waste [2]

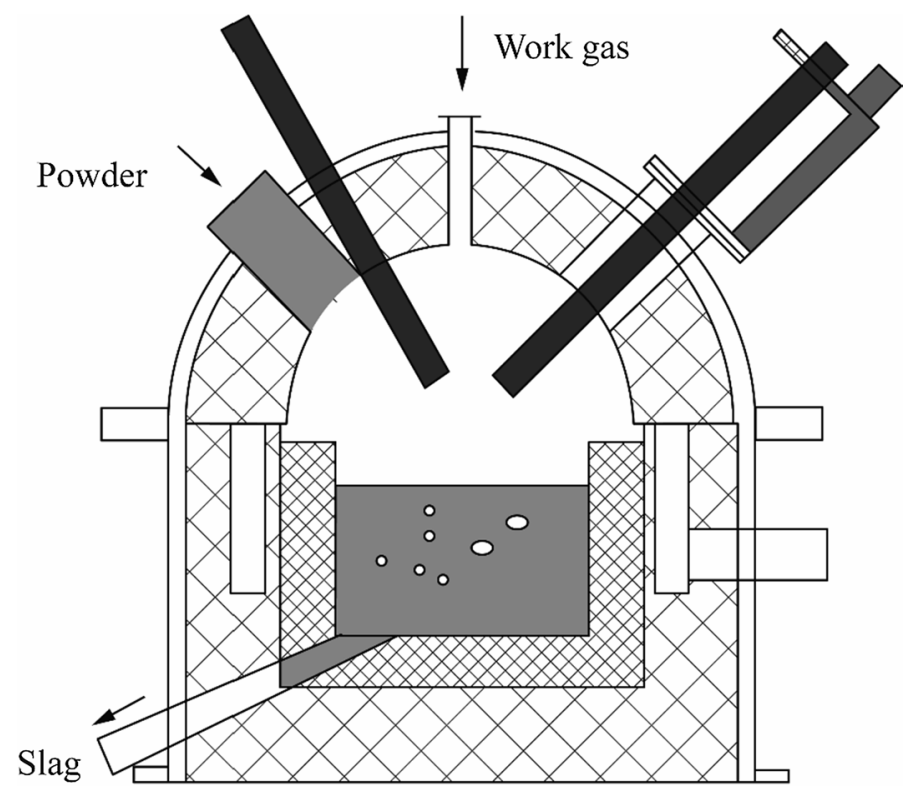

Fig. 5 Schematic of a pilot AC plasma furnace for treating medical waste, POPs, etc. [60]

organic wastes are rapidly pyrolyzed and produce off-gas. Once the off-gas passes the gasburning subsystem and burns, combustible components are removed. After this treatment, the off-gas passes through a series of gas cleaning units for acid-gas recovery and removing other gas pollutants. Then the cleaned off-gas discharges at the stack. 


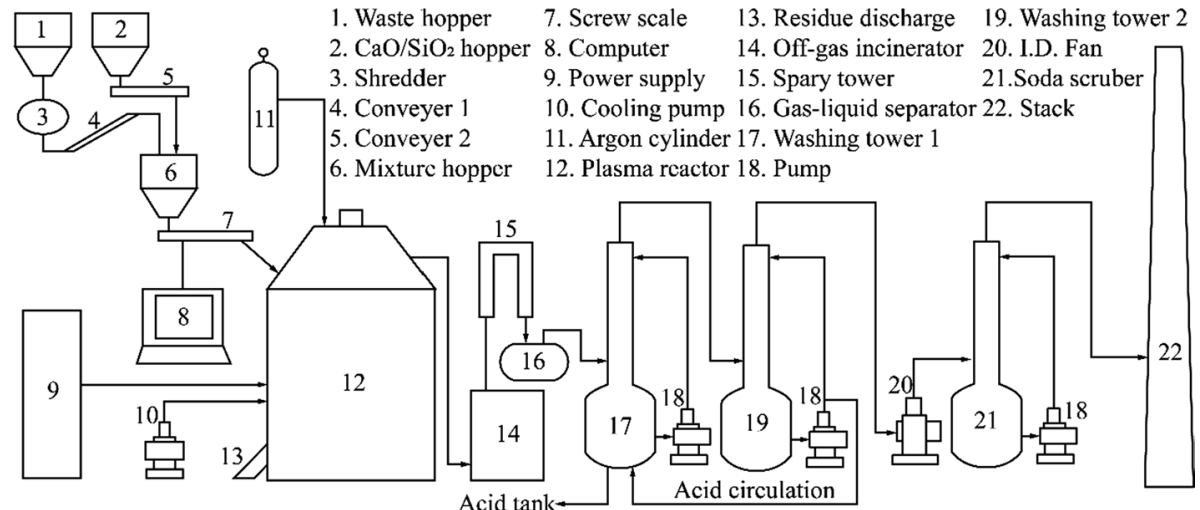

Fig. 6 Schematic description of the pilot AC plasma pyrolysis system for treating chemical waste [61]

A Plasma Energy Pyrolysis System (PEPS) aiming at converting multiple waste streams into fuel gas and inert slag is presented in Fig. 7 [59]. The major subsystems include waste feed, plasma heating, processing vessel, gas emission control, wastewater treatment, and other supporting systems. It installs a $500 \mathrm{~kW}$ non-transferred plasma torch, which produces a temperature range of 1643-1923 K for decomposing waste. Meanwhile, the addition of steam further increases the energy content of the produced syngas. The pyrolysis

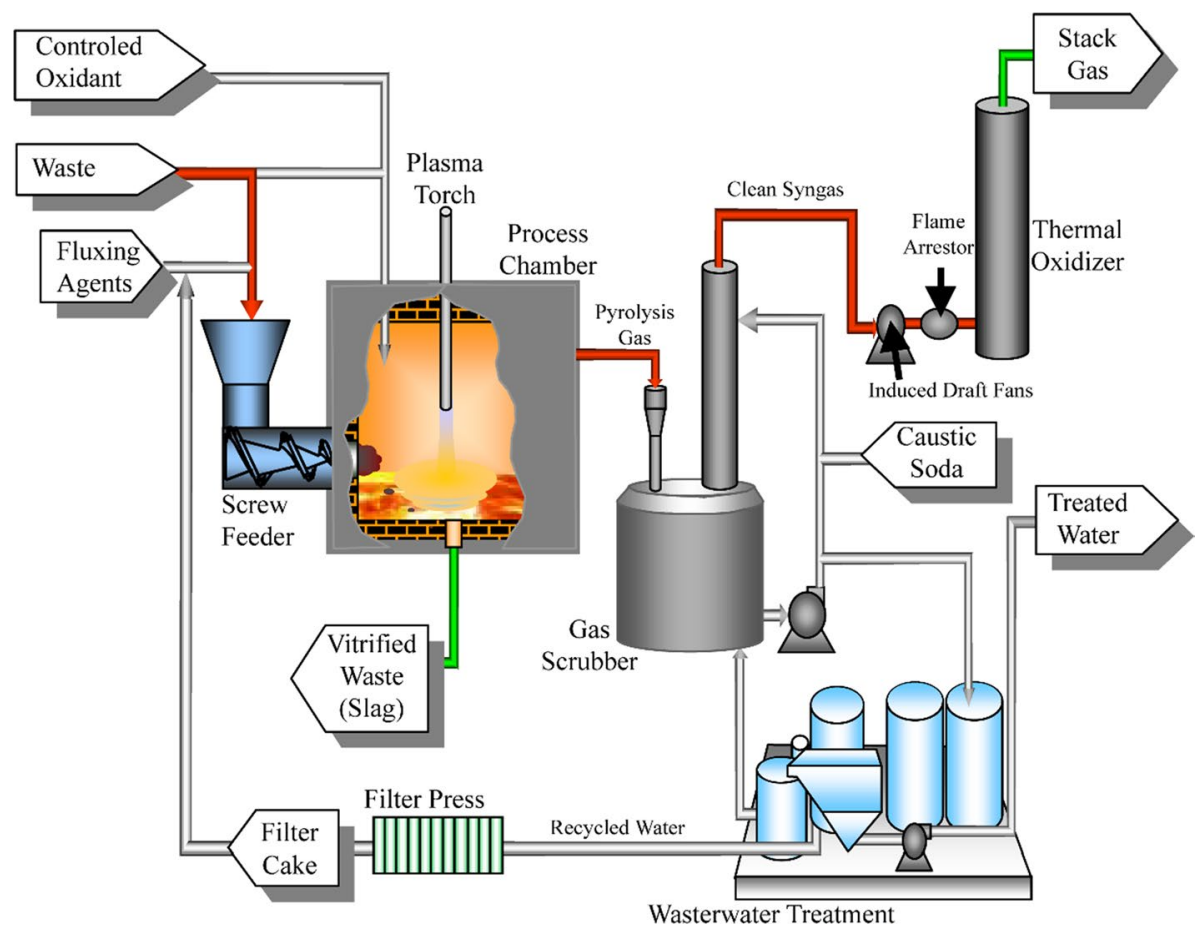

Fig. 7 Schematic diagram of a plasma pyrolysis process for medical waste treatment [59] 
gas is then cleaned to remove impurities by a gas scrubber, and this wastewater has to be treated. The solids produced from the wastewater treatment subsystem are reprocessed in the process. The cleaned high-energy syngas is proposed to drive a device for energy recovery or be converted to produce benign substances. The metals in slag were melted into the silica-based structure, and metals recovery can be achieved in highly reducing conditions.

Sampathraju and Mansuri [62] assessed the air pollutant of plasma pyrolysis of biomedical waste which located in Ahmedabad city of India. The plasma pyrolysis system consists of a transformer, power supply panel, feeder, plasma torch with LH cathode, RH cathode and anode, primary chamber, sparker, secondary chamber, ventury, scrubber with their pump, ID fan, and water tank. The facility has the capacity to dispose of $15-20 \mathrm{~kg}$ of biomedical waste. Their assessments showed that the concentration of particulate matter (SPM and RPM or PM10), CO, $\mathrm{SO}_{2}, \mathrm{H}_{2} \mathrm{~S}, \mathrm{NO}, \mathrm{Cl}_{2}$ and total VOCs were well within national ambient air quality standards $(\mathrm{CPCB}, 009)$ and within permissible exposure limit (PEL) of Indian Factories Act, 1948.

\section{Plasma Gasification Process}

Plasma gasification is the incomplete oxidation of organic matters, converting them into a combustible or synthetic gas (a mixture of $\mathrm{H}_{2}, \mathrm{CO}, \mathrm{CO}_{2}, \mathrm{CH}_{4}$, and other hydrocarbons) $[22,45,54]$. For waste containing inorganics, the inorganic fraction is vitrified into a nonleachable slag simultaneously [84]. Compared with conventional gasification, it has a smaller installation and cleaner air emission but consumes more energy. Janajreh et al. [84] evaluated the gasification efficiency of these two methods based on various feedstock and found the efficiency of plasma gasification was lower than that of conventional air gasification (the value is around $42 \%$ for plasma and $72 \%$ for the later). Compared with incineration, plasma gasification only introduces a limited quantity of $\mathrm{O}_{2}$, in which the generations of $\mathrm{NO}_{\mathrm{x}}$ and $\mathrm{SO}_{\mathrm{x}}$ are prohibited in such an $\mathrm{O}_{2}$-starved environment [85]. Typical post-processing equipment for the treatment of off-gas is composed of the wet scrubber, particulate filters, or other gas cleaning devices. Similar to plasma pyrolysis, the gaseous product from the plasma gasification furnace can be used for the production of energy and fuel. The energy resulting from the syngas as well as the exhaust heat is proposed for the further generation of electricity or hot water. For the maximization of syngas, some commercial process adds pre-gasifier to preliminarily process a majority of organic matters (e.g., the PEM process from InEnTec) [86].

Medical waste with high organic content is suitable for plasma gasification, which is an effective waste-to-energy technology. As shown in Fig. 8, the plasma steam gasification system with a capacity of $50 \mathrm{~kg} / \mathrm{h}$ was built by the Gas Institute of the National Academy of Sciences of Ukraine (NASU) and the E. O. Paton Electric Welding Institute, NASU [66]. The core component, plasma torch has electrical power reaching up to $160 \mathrm{~kW}$, power supply voltage $500 \mathrm{~V}$, and arc current is up to $350 \mathrm{~A}$. Steam generator generates steam to act as the gasifying agent with additionally introduced oxygen, and the high-temperature dense plasma effuses into the internal space of the reactor. The medical waste is rapidly gasified at the temperature above $1100{ }^{\circ} \mathrm{C}$ and produces gases like $\mathrm{H}_{2}, \mathrm{CO}, \mathrm{CO}_{2}, \mathrm{CH}_{4}$. After that, the off-gas is cooled in the gas quenching system. The smoke exhauster provides gasification products extraction and creates a rarefaction in the reactor toward the atmosphere, to prevent any penetration of these products into the environment. The gasification products cleaning unit removes pollutants in the gas phase. Meanwhile, the heat exchanger is installed for recovering heat from the off-gas. 


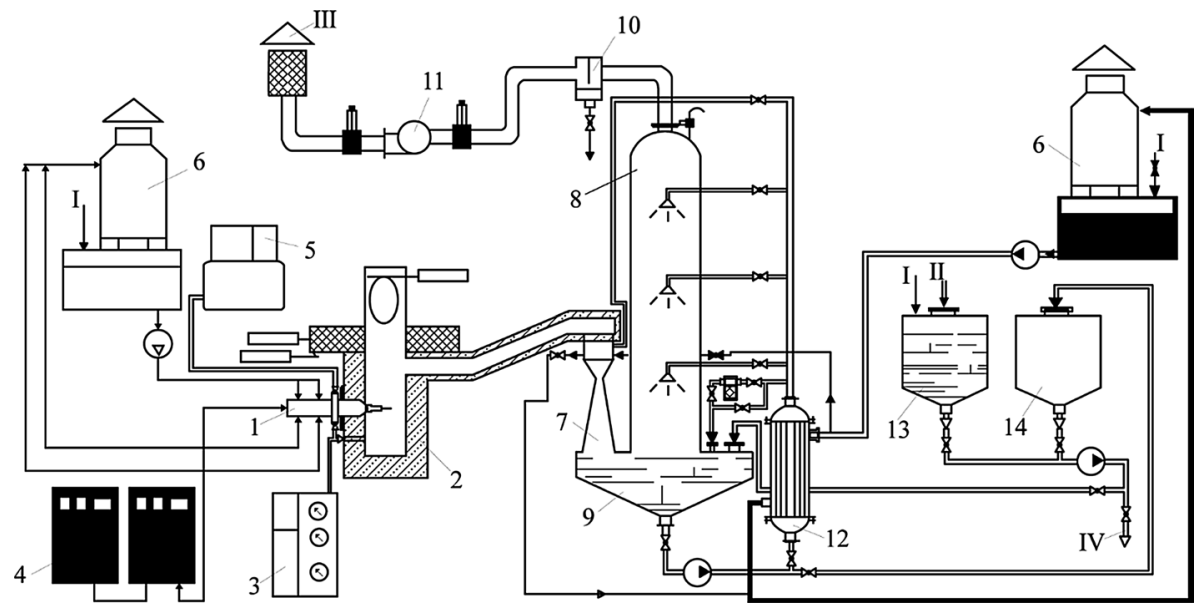

Fig. 8 Schematic diagram of a plasma steam gasification process [66]. 1: plasma torch, 2: plasma steam reactor, 3: steam generator, 4: sequentially connected power sources plasma-2, 5: compressor, 6: cooling tower, 7: Venturi scrubber, 8: system for the gas quenching, 9: under-scrubber capacity, 10: drip pan filter, 11: fan (smoke exhauster), 12: heat exchanger, 13: soda solution tank, 14: sludge tank, I: water supply, II: soda, III: synthesis gas, IV: for utilization

Messerle et al. [68] described a biomedical waste (BMW) plasma gasification process, as shown in Fig. 9. The experimental facility includes a power supply system, a control system of the plasmatron, a plasma reactor, gas and water supply systems for the reactor with the plasmatron, and a purification system for off-gases. The primary components are a DC plasmatron with a rated power of $70 \mathrm{~kW}$ and a plasma reactor. The briquetted BMW ( $0.4 \mathrm{~kg}$ each briquette) is loaded into the gasification zone of the reactor through the loading inlet. When undergoing gasification, the air plasma torch provides a mass-mean temperature up to $1700 \mathrm{~K}$, decomposing organics into syngas and other gases. After that, the formed gaseous products are extracted out of the reactor into the cooling system. Whereas the condensed products are accumulated in the slag formation zone at the bottom of the reactor. Following the cooling treatment, the

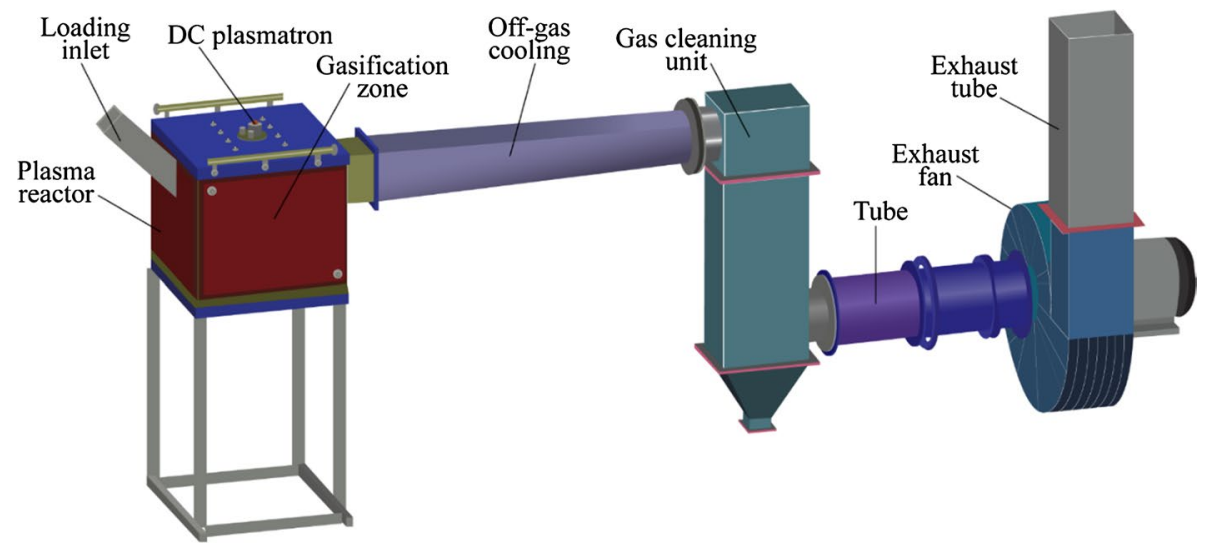

Fig. 9 Scheme of the experimental facility for biomedical waste plasma gasification [68] 
gases enter the gas cleaning unit and, afterward, the gas is conveyed to the gas analyzer through the exhaust gas tube with the system for gas sampling and temperature measurement. The whole cycle of processing is about $30 \mathrm{~min}$, which ensures high temperature and enough time to preclude the formation of dioxins and furnace.

The plasma gasification process has the advantage of being able to produce syngas and other valuable products [45]. The co-treatment of medical waste and fly ash using plasma gasification was conducted by Zeng et al. [87] to produce an effective catalyst. To determine the effects of raw materials ratio on the produced slag, the researchers performed a series of feed-material ratios between medical waste and fly ash to produce slags. Then the slags were used in selective catalytic reduction of nitric oxide. The results showed that co-treatment would benefit the formation of glass-phase slag, whereas increased the amount of transition metal in the slag, regulating the valence difference, thus increasing SCR activity. Meanwhile, some metals such as $\mathrm{Zn}$ and $\mathrm{Pb}$, are enriched in the secondary ash that can act as a kind of mine resource. This study has identified the co-treatment of medical waste and other hazardous waste is a potential method to obtain high-value-added products. A plasma gasification system with $60 \mathrm{~kg} / \mathrm{h}$ purchased from PEAT International was designed for medical waste, which is the first commercial operating plasma gasification system in China [67]. The industrial operation showed that the emission levels near European standards (2000/76/EC) and significantly below Chinese regulations (GB 18484-2001).

\section{Plasma Vitrification Process}

Conventional incineration is not suitable for treating non-combustible waste, thus presorting is necessary. For these hazardous wastes, another method is to use the vitrification process, which obtains a glassy and leach-resistant product that solidifies and stabilizes toxic substances. Various vitrification technologies include but not limit to combustion-based melters, fluidized bed gasifying melting systems, Joule heated melters, electric arc furnaces, plasma melters, etc. [88]. Plasma vitrification offers smaller installation but also consumes more energy. A high fraction of non-combustible materials of medical waste is suitable for such a process. It should be noticed that this process inevitably coexists in a plasma pyrolysis process or plasma gasification process for a multi-component waste. The dominance of the vitrification depends on the proportion of inorganic components and the addition of additive $\left(\mathrm{SiO}_{2}\right.$, etc. $)$.

The Institute of Nuclear Energy Research (INER) in Taiwan investigated the feasibility of medical waste treatment using thermal plasma treatment [89]. The simulated feedstock contained a high ratio of noncombustible substances such as stainless steel and glass. In this study, $\mathrm{ZnO}$ was selected as a tracer metal being spiked into the surrogate before treatment for evaluating the vitrification effectiveness. As shown in Fig. 10, the waste feed is placed at a cylindrical crucible container to prevent the waste from overflowing or spreading during the treatment. A $100 \mathrm{~kW}$ non-transferred arc plasma torch is positioned in the top of the chamber, generating plasma in which the temperature could be in excess of $10,000{ }^{\circ} \mathrm{C}$ and with an electron density of $6 \times 10^{22}$ / $\mathrm{m}^{3}$ at the centerline. Ar is used as the plasma gas for ignition and, after ignition, the air is used during the treatment. The vitrification treatment lasted $15 \mathrm{~min}$ at $1550{ }^{\circ} \mathrm{C}$. After plasma vitrification, two macroscopic components-vitrified glassy slag and ellipsoidal metal nugget were obtained. 


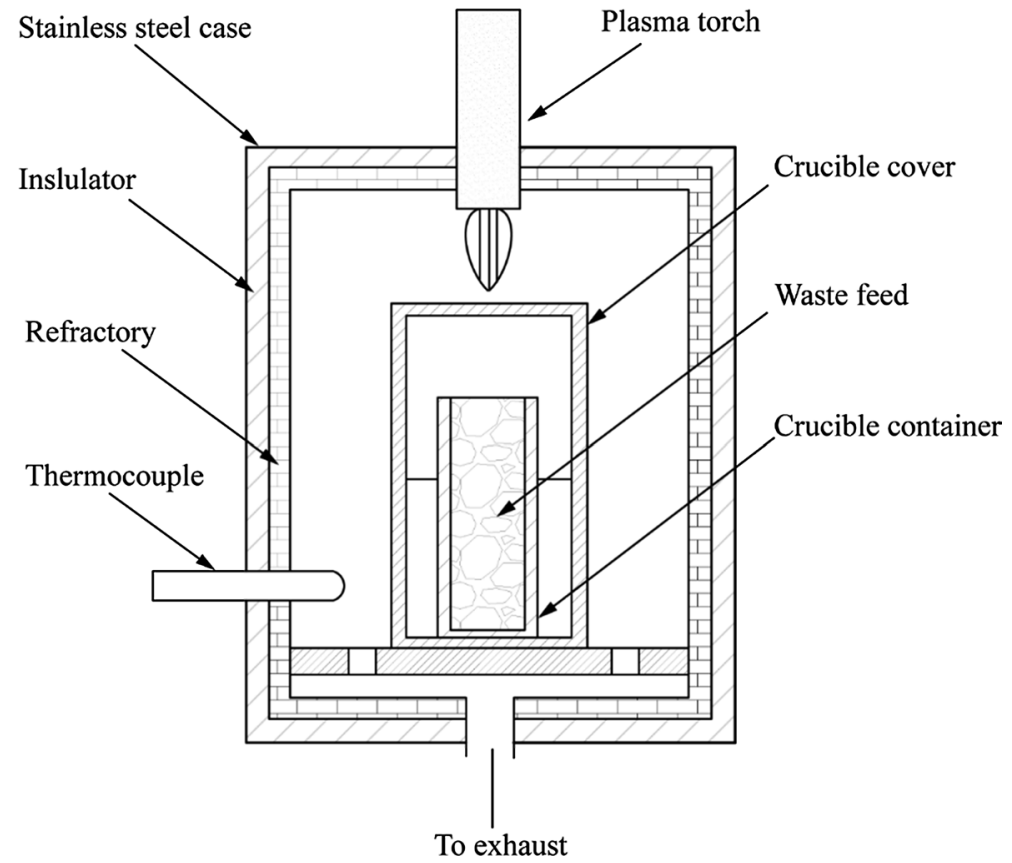

Fig. 10 A schematic of the INER plasma vitrification system for treating medical waste surrogates [89]

\section{Plasma Reactor Configuration}

In terms of the plasma discharge ways, the thermal plasma reactor can be classified into four types: direct current plasma reactor (transferred arc reactor and non-transferred arc reactor), alternating current plasma reactor, radio frequency plasma reactor and microwave plasma reactor $[54,90]$. The most commonly used reactor is the direct current plasma reactor, which has the problem of electrode contamination and erosion. Therefore, the RF plasma system for medical waste treatment was proposed by some researchers [91]. While, the development of the AC plasma torch also receives people's attention in Russia and the United States [57, 92]. In this paper, we investigated the existing plasma medical waste systems and attempted to classify their plasma reactors. For a specific furnace, there are overlaps among these categories for emphasizing the characteristics of the furnaces.

\section{Fixed/Moving Bed Furnace}

The fixed/moving bed furnace is the basic furnace type which is the most commonly used one. This type of furnace offers the advantage of easily operating and is suitable for treating bulk materials, which has great applications in industry. However, due to the waste is in continuous contact with the plasma, some intermediate products wanted may not be obtained. Many thermal plasma systems of medical waste are designed based on this type.

In the fixed bed furnace, medical waste to be treated is placed at the bottom of the reactor in advance (to treat in batch), where the plasma jet spouts out and contact with the 
waste. Generally, the plasma torch is mounted in the top of the furnace vertically or the side at a specific angle. For example, Fig. 10 describes a plasma vitrification system using a fixed bed furnace [89]. This furnace wall consists of three layers: the stainless steel case, the insulator, and the refractory. The chamber is designed to obtain optimal uniform temperature distribution by controlling the airflow rate and DC plasma current. The medical waste is placed in the cylindrical crucible container with a size of $\phi 63 \times 105 \mathrm{~mm}$ (length) and consisting of $10 \mathrm{wt} \% \mathrm{Cr}_{2} \mathrm{O}_{3}$ and $90 \% \mathrm{Al}_{2} \mathrm{O}_{3}$. During the treatment, the waste is needed to be covered with the crucible to avoid an overflow or spreading.

For moving bed furnace, medical waste is fed into the reactor through the inlet from the top or side of the reactor, which offers the advantage of continuous operation and increasing treatment capacity over the fixed bed furnace. As shown in Fig. 11 (partial view of Fig. 2) [5], the furnace is an inclined tube reactor where a screw conveyor insight is used to transport the waste to the water-cooled mixing chamber at the end of the tube. The maximum mass flux of feeding can reach $40 \mathrm{~kg} / \mathrm{h}$ for continuous feeding. The position of the feeder and plasma torch is arranged differently. Figure 12 shows a plasma process is used to treat medical waste, contaminated soil, and municipal solid waste [93]. The plasma jet is in contact with the waste vertically.

\section{Multi-chamber Furnace}

The system with multi plasma chambers generally includes two chambers, the primary chamber produces gaseous products that enter the secondary chamber for further treatment. Both chambers install plasma torch.

The secondary treatment varies depending on the target products or emission. It could be directly combustion of combustible gas (or the oxidation of toxic gases), upgrading the combustible gases for further application, or extracting specific chemical agents. A variety of furnace types are available for the primary chamber. Except for the furnace mentioned in "Fixed/Moving Bed Furnace" section, a lined rotary kiln with AC plasma torches was designed for the treatment of $150-200 \mathrm{~kg} / \mathrm{h}$ of hazardous medical waste, as described in

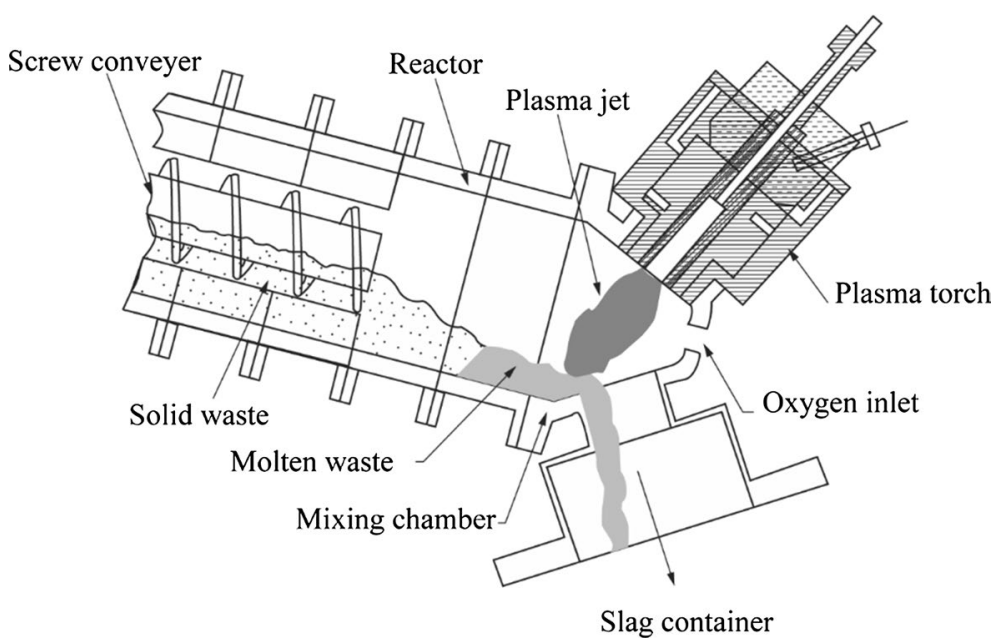

Fig. 11 Moving bed furnace for medical waste disposal [5] 


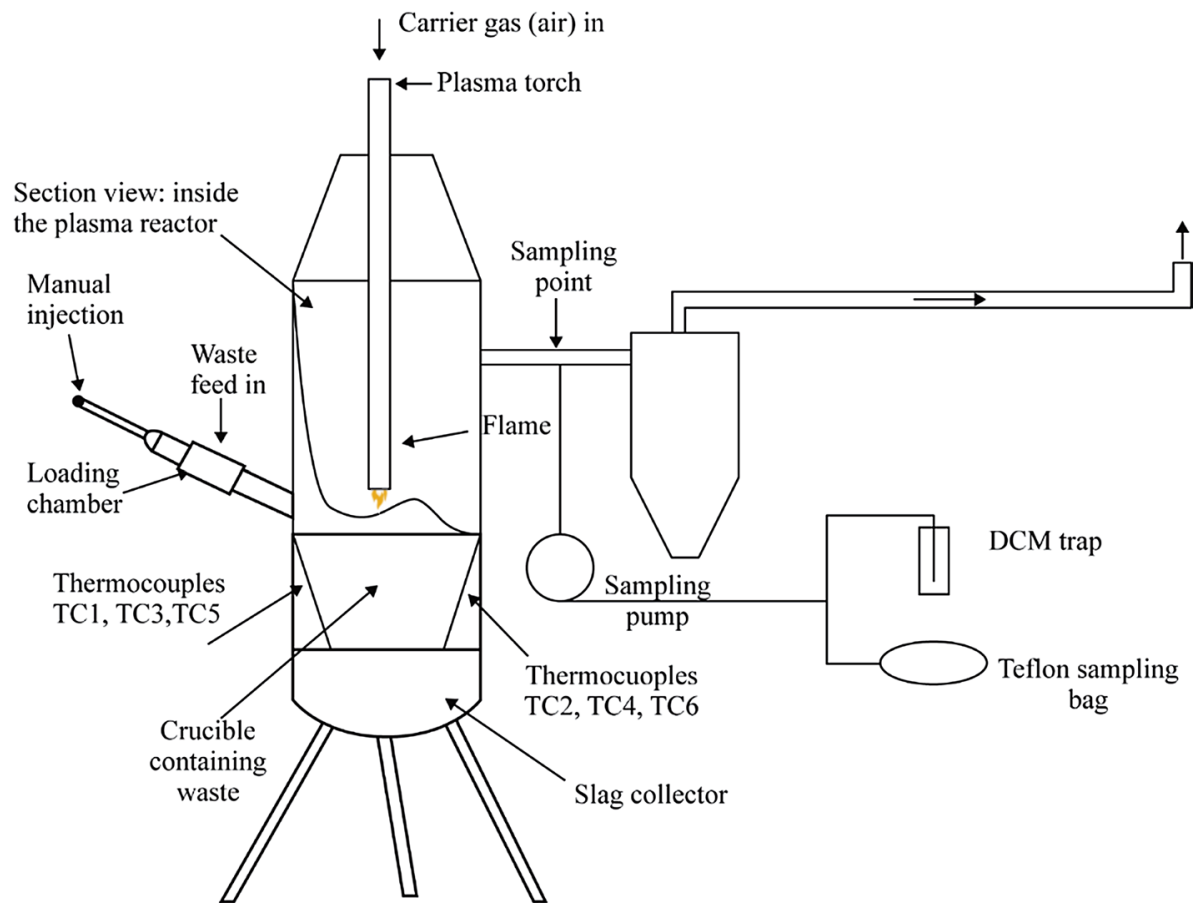

Fig. 12 Schematic of a plasma treatment system in Plasma Application and Research Facility (PARF) [93]

Fig. 1 [57]. The rotary kiln is employed at an angle to the horizon and rotates. The advantage of this type of furnace is that it maintains the waste constantly stirred, thus intensifying the processes of heat and mass exchange. For plasma combustion, the secondary chamber plays a role in removing a small amount of combustible gas and other toxic organic products with additional additions of air and water as mentioned earlier. Parameters of experience are set to a temperature range of $1200-1400{ }^{\circ} \mathrm{C}$ and dwell time of $\sim 2 \mathrm{~s}$ [57]. In previous studies, another plasma torch was installed in this module [57, 58], or the module was not set due to lower capacity, enhancement of oxygen, and the loop of the flue gas [5]. For plasma pyrolysis or gasification, the secondary chamber is one of the options to recovery energy (plasma torch is probably not used). Direct combustion of the fuel gas in lab-scale setups is to burn off combustible gas for emission, and the gas cleaning subsystem may position before it in some cases [59]. However, when the project is scaled up, the energy should be recovered, and the quality of syngas must upgrade depending on the requirement of the syngas utilization equipment.

The secondary chamber is separated (common) or integrated with the primary chamber (an example of the latter one can be seen in Fig. 3). In Fig. 3 [58], the plasma combustion chamber is the main component in the integrated furnace, which is a metal vertical rectangular shaft cooled by air. Internally the shaft is lined with a light-weight chamotte brick. In the bottom, there are three rows of chamtte brick upon which a bath made of silicicated graphite is placed to accumulate molten metal and non-organic components of the waste with an opening for flowing out the melt into a slag receiver. The plasma jet attacks the bottom of the bath at an angle of $45^{\circ}$ where the temperature is so high that the liquid slag 
probably interacts with the silicicated graphite bath. Therefore selecting structural materials for high-temperature operation is also needed in further study. The second plasma duct installs a plasma torch up to $15 \mathrm{~kW}$ which is placed horizontally. The torch is placed in a silicicated graphite tube where the additional air is fed. The furnaces with two separate chambers are commonly used in plasma combustion, pyrolysis, and gasification. An example of plasma combustion is a case carried out by a rotary kiln (installed two AC plasma torch) and an afterburner (installed an AC plasma torch) as shown in Fig. 1 [57]. In Fig. 4 [2], the inclined primary chamber (pyrolysis chamber) is made up of mild steel and has a waste-feeding arrangement, mild-steel shell, glass-wool shielding, etc. Before entering the chamber, the waste has to pass through a double-door feeder which operates pneumatically and alternately. The inner door has a fish-mouth locking which avoids leakage of the gas. The outer door has proper sealing to prevent gases from escaping to the atmosphere when the inner door is opened for feeding the material. Inside the chamber, the plasma torch is installed on a flange of $100 \mathrm{~mm}$ diameter in a side port. The secondary chamber uses a burner to combust hot gases that contain hydrocarbons, carbon monoxide and hydrogen produced in the primary chamber.

\section{Multi-torch Furnace}

According to the investigations covered in our review, DC plasma torch (transferred and non-transferred) and AC plasma torch have been used, and the former is more extensive. With the expansion of the scale, it is necessary to increase the power of the plasma system. However, these high powers only can be achieved by using high current in most of the thermal plasma systems, which significantly increase the erosion of electrons and thus reduce the lifetime of plasma torch [16]. In addition to this, the operating life of plasma system is closely associated with the type of torch, waste stream, plasma gas (or reactor environment). Meanwhile, furnace installed a single plasma torch may suffer from uneven heating with the increased capacity. In Fig. 7, the used DC non-transferred torch is capable of three-axis movement to address this issue [59]. Another possible solution is to design a multi-torch plasma furnace, which is a more effective device for treating medical waste.

In Fig. 2, two DC non-transferred arc plasma troches are installed with a total power of $20 \mathrm{~kW}$ for each torch [5]. Not only DC plasma torch but also AC plasma torch has been employed this torch arrangement [57]. In a single multiphase AC plasma torch, several arcs can coexist to create a larger volume zone [94]. Combining with multi-torch, it can effectively deal with a larger treatment capacity. Figure 13 shows the experimental setup of the multi-torch plasma arc [50]. The crossing angle between cathode and anode is $98^{\circ}$, and a third nozzle locates at the middle top of the chamber. The maximum DC arc current of the dual and multi torch plasma arc is $100 \mathrm{~A}$ (I). It is found that at the same arc length (L), the voltage of multi and dual torch plasma arc is larger than that of a single torch plasma arc. For example, the voltage and input power of the multi torch plasma arc is 1.1, 1.4 times than that of the dual torch plasma arc and the single torch plasma arc, respectively, in the case of $\mathrm{L}=3 \mathrm{~cm}$ and $\mathrm{I}=100 \mathrm{~A}$. Although the temperature of multi torch near the cathode is lower, the temperature distribution area of multi plasma arc is double or much wider than those of the dual and single torch plasma arc. Besides, the heating efficiency of a single torch is high than that of dual torch. However, the dual torch the arc voltage fall at the electrode is $6 \mathrm{~V}$ which is higher than that for the single torch. This means that the efficiency of the dual torch could be much higher. Such a furnace with a power source capacity of 


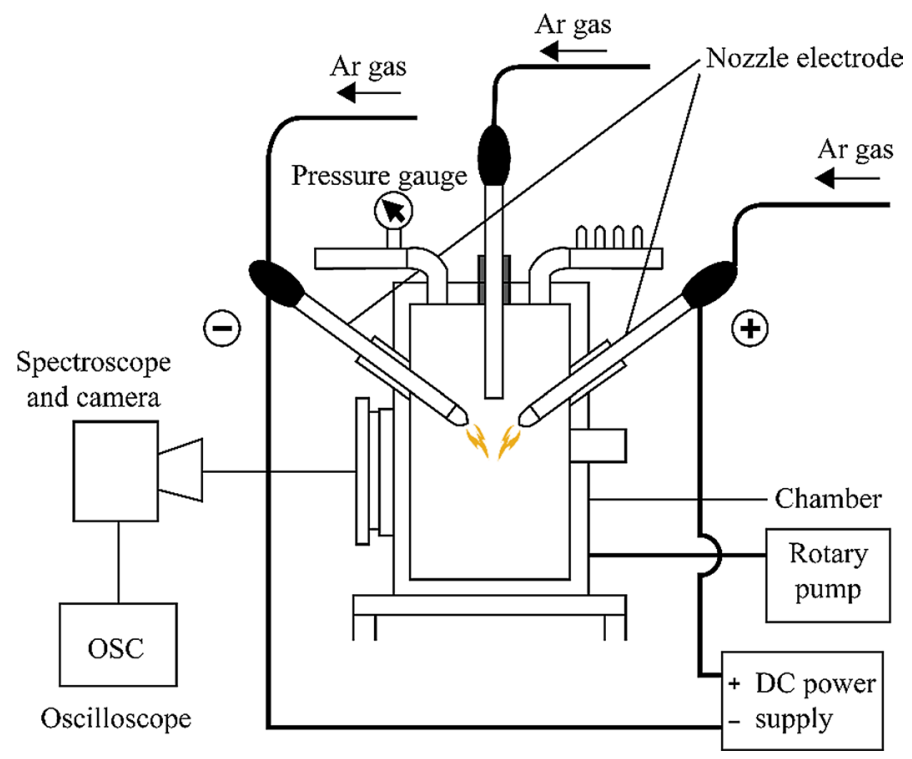

Fig. 13 Schematic diagram of the multi-torch plasma furnace for treating medical waste [50]

$300 \mathrm{~kW}$ has been developed the Chuo University, Musashi Institute of Technology and Shinwa Industry Co. Inc. in Tokyo, Japan [50].

\section{Fixed/Mobile Furnace}

One of the biggest advantages of themal plasma technology is its smaller and compact installation as well as the short start-up and shut-down time, which may play a potentially useful role as the mobile treatment system has become increasingly important in the management of medical waste. There are several studies reported their setups allowing mobile operation in arenas of medical waste treatment with thermal plasma technology.

The PEPS system shown in Fig. 7 is fixed/transportable, and another mobile version was also under construction [59]. Sheng et al. [60] reported a mobile AC plasma pyrolysis system and pointed out this advantage resulted from its fast pre-heating process and short start-up and shut-down time (only several minutes). The plasma chamber showed in Fig. 13 also has a mobile version with a size of $\phi 1500 \mathrm{~mm} \times 2200 \mathrm{~mm}$ (length) and a crossing angle of the electrodes $60^{\circ}$ [50]. The temperature of the dual torch plasma arc at the center point was measured to be $11,000 \mathrm{~K}$ in the case of $200 \mathrm{~A}$ in arc current and $30 \mathrm{slpm}$ in plasma gas flow rate of argon gas in an air atmosphere at $0.1 \mathrm{MPa}$. Complete system equipment can be put on a commercial 5.5-ton truck to allow the treatment of wastes on-site.

\section{Other Types of Furnace}

Fluidized bed furnace, entrained-flow bed furnace and spout/spout-fluid bed furnace are less used in the thermal plasma treatment of medical waste, the detailed introduction can be found in the paper of Tang et al. [95]. The fluidized bed furnace is used in the pyrolysis and gasification process, in which the specific agent creates a fluidized state in the furnace. It can offer excellent heat transfer, a high degree of mixing, nearly constant temperature 
and great operating flexibility. In the entrained-flow bed furnace, the feedstock in which the powder to be treated is injected in the tail flame of a plasma jet. Its advantages include the high temperature, ultra-short contact time reactions with the intermediates as the desired products, however, with lower energy efficiency is lower. In the spout bed furnace, a DC plasma jet forms the spout which provides heat for the process. Its potential advantages are higher operating temperatures, high degrees of conversion with short residence times, whereas also suffering from problems of bed stability. Plasma spout-fluid bed furnace is a combination of a fluidized bed and plasma spouted bed. It is characterized by perfect mixing of the particles, high rate of heat and mass transfer, continuous operation with solid, high apparent density of solid and high temperature.

\section{Parameter Influences on Products Yield and Treatment Effect}

The composition of medical waste varies widely, which may contain only inorganic material or can consist of very humid and organic material. Therefore specific medical waste may be suitable for different plasma treatment processes. The following discussions about the parameter influences may be different under diverse conditions with different desired products. There are rare previous reports in the literature on the generation of liquid products during a thermal plasma process including plasma pyrolysis, which is very different from conventional pyrolysis. We believe the possible reason is that reactive plasma species and higher temperatures reduce the yield and selectivity of liquid hydrocarbons. The temperature may be the key factor since fuel oil also could be obtained at a lower temperature range of $625-890^{\circ} \mathrm{C}$ using a DC thermal plasma [96]. It can be concluded that gas production is dominant over liquids in the thermal plasma process when the temperature is high enough. The solid products may be obtained in the forms of slag, ashes, and particles in the gas phase depending on the employed thermal plasma technology, the feedstock nature, and the operating conditions. Thermal plasma technology is not only suitable for treating medical waste but also achieves good treatment performance in treating fly ash from medical waste incinerators. PCDD/Fs was decomposed with over $99 \%$ and the leaching of heavy metals was significantly decreased achieved by Pan et al. using a DC double arc plasma torch [97]. An investigation conducted by Sobiecka et al. [98] has been demonstrated that vitrificates derived from incinerated medical waste ash using thermal plasma vitrification technology have very low metals leaching. It is expected to reduce the requirement for further treatment in the management of medical waste by applying thermal plasma technology. This section focuses on the gaseous and solid products influenced by several factors, as well as other beneficial treatment effects such as mass/volume reduction and pathogen destruction.

\section{Gaseous Products}

\section{The Influence of Different Thermal Plasma Processes and Feed Composition}

It can be seen from Table 5 that plasma combustion mainly generates $\mathrm{CO}_{2}$ and $\mathrm{H}_{2} \mathrm{O}$, while syngas with a smaller amount of hydrocarbons is the major gas composition of plasma pyrolysis and plasma gasification. Plasma gasification generally has a higher syngas production than plasma pyrolysis. This, in principle, can give rise to that plasma gasification can be regarded as a further reaction of pyrolysis. 
According to Park et al. [58], the process of plasma combustion can be divided into several stages: the stage of heating, the stage of emission and burning of volatiles, and the stage of afterburning of the coke-ash residual bound carbon. However, owing to the high temperature, the heating stage can be ignored. It is supposed that the decomposition of the organic part of the wastes and the emission and combustion of the volatiles begins instantly. Therefore, plasma combustion is different from conventional incineration. In the plasma process conducted by Park et al. [58], the main gas composition is $\mathrm{CO}_{2}, \mathrm{CO}$, $\mathrm{O}_{2}$, and $\mathrm{N}_{2}$. The dynamics of the $\mathrm{CO}_{2}$ concentration showed that it sharply increased to 5-8 vol\% after charging, and within 2-5 min this value remained constant before it slowly (8-12 min) decreases to the background. Whereas the $\mathrm{CO}$ concentration may sharply increase followed by a rapid fall to the background value within $1 \mathrm{~min}$. In the case of $\mathrm{AC}$ plasma combustion [57], owing to the composition of medical waste, inevitably $\mathrm{HCl}, \mathrm{Cl}_{2}$, $\mathrm{COCl}_{2}, \mathrm{C}_{2} \mathrm{~F}_{4}, \mathrm{CF}_{4}, \mathrm{C}_{2} \mathrm{~F}_{6}$, and chlorine-organic compounds would be formed in the furnace. Some of them like $\mathrm{C}_{2} \mathrm{~F}_{4}, \mathrm{CF}_{4}, \mathrm{C}_{2} \mathrm{~F}_{6}$ will be fully transformed only at high temperatures and in the presence of water vapor. When the sulfur is contained in the waste, $\mathrm{SO}_{2}$ is formed with the oxygen in the air, while $\mathrm{H}_{2} \mathrm{~S}$ is formed when oxygen is in deficiency. Soot formation is caused by oxygen deficiency as well as the production of $\mathrm{CO}$ and $\mathrm{H}_{2}$, therefore they can be reduced to a small amount with an excess of air.

In a study of plasma pyrolysis, typical gaseous products are hydrogen and carbon monoxide, with some lower hydrocarbons [2]. $\mathrm{H}_{2}$ and $\mathrm{CO}$ in the gaseous mixture is more than $49 \%$ in volume, others are mainly $\mathrm{N}_{2}(45.04 \mathrm{vol} \%)$. Similar results were achieved by many other studies, which means the syngas is major products or intermediate products in the thermal plasma treatment $[59,81]$. Among these investigations, the difference of syngas composition partly caused by the feed composition. This also can be seen in the plasma gasification process [68]. It was noticeable that hydrocarbons were reduced to a low level in the plasma pyrolysis process. A possible explanation for this might be that the induced air in the primary chamber reacts with them and produce $\mathrm{CO}$ and $\mathrm{CO}_{2}$. Meanwhile, when steam was introduced to the primary chamber, the soot formation was restricted to some extent and therefore leading to the production of $\mathrm{CO}$ and $\mathrm{CH}_{4}$. As can be seen from Table 5, $\mathrm{CO}$ and $\mathrm{CO}_{2}$ reach $26.65 \%$ and $4.20 \%$ respectively. After combustion, all toxic components of the gas mixture, i.e. $\mathrm{CO}, \mathrm{NO}_{\mathrm{x}}$, and $\mathrm{SO}_{2}$ are present in low quantities. The $\mathrm{SO}_{2}$ may come from the rubber in the polymeric waste. Meanwhile, $\mathrm{HCl}$ would form when polyvinyl chloride or other chlorinated wastes are present in the waste. When the raw material is chemical waste in a plasma pyrolysis process, the experiments conducted by Li et al. [61] showed that the main gaseous products are $\mathrm{C}, \mathrm{CH}_{4}, \mathrm{H}_{2}$, and $\mathrm{HCl}$. $\mathrm{HCl}$ produced in the pyrolysis gas can be neutralized by $\mathrm{NaOH}$ solution in the gas-cleaning unit.

\section{The Influence of Temperature}

In a thermodynamic study of water-steam plasma pyrolysis of medical waste [6], different temperature changes the gas composition obtained. The organic parts of medical waste applied to the simulation experiment included cellulose, polypropylene, polyethylene, polystyrene, organic tissue, and PVC. Apart from PVC, other organics almost produced CO and $\mathrm{H}_{2}, \mathrm{CO}_{2}, \mathrm{C}_{2} \mathrm{H}_{4}, \mathrm{CH}_{4}$, etc. decreased sharply at the temperature range of 1000-1200 K and down to nearly zero at about $1400 \mathrm{~K}$. Between 1400 and $2000 \mathrm{~K}$, the amount of CO was stably maintained in which the cellulose reaction obtained the highest $\mathrm{CO}$ content up to $50 \mathrm{vol} \%$. While the $\mathrm{H}_{2}$ first maintained equilibrium as the temperature increased and then gradually decreased after $2500 \mathrm{~K}$. For the case of PVC reaction [6], the volume of 
$\mathrm{CO}$ and $\mathrm{H}_{2}$ was up to $82 \%$, the admixtures $\left(\mathrm{CO}_{2}, \mathrm{C}_{2} \mathrm{H}_{4}, \mathrm{C}_{2} \mathrm{H}_{2}, \mathrm{CH}_{4}\right.$, etc.) was less than $1 \%$, the $\mathrm{HCl}$ was about $17 \%$ with the temperature range of 1400-2000 K. It was observed that above $2500 \mathrm{~K}$, the amount of $\mathrm{CO}$ and $\mathrm{H}_{2}$ would reduce and $\mathrm{H}$ would increase. Meanwhile, the amount of $\mathrm{C}, \mathrm{CH}, \mathrm{C}_{2} \mathrm{H}_{2}, \mathrm{O}, \mathrm{OH}$, etc. increased slightly. Therefore, the researchers suggest that the temperature should be controlled between 1300 and $1500 \mathrm{~K}$ for less power consumption and more hydrogen-rich syngas. This study demonstrated that the degree of raw material transformation to $\mathrm{CO}$ and $\mathrm{H}_{2}$ is about $100 \%$ in the $\mathrm{C}-\mathrm{H}-\mathrm{O}$ system of $\mathrm{C} / \mathrm{O}=1$ in the temperature range of 1400-2000 K. In the case of pyrolysis of chemical waste [61], the increase of $\mathrm{H}_{2}$ and the decrease of $\mathrm{C}, \mathrm{CH}_{4}$, and $\mathrm{HCl}$ with increasing temperature were also observed below $1000 \mathrm{~K}$. However, between 1000 and $2500 \mathrm{~K}$, the variations change slightly. The results confirm once again that temperature should be optimized to recover combustible gas and reduce energy consumption.

In a study of plasma gasification of biomedical waste [68], the numerical simulation was carried out. The influences of temperature on the gaseous products are shown in Table 4. When dry bony tissue (BT) was processed, it was observed that the syngas $\left(\mathrm{CO}+\mathrm{H}_{2}\right)$ increased with the increased temperature and reached the maximum values at $\mathrm{T}=1300 \mathrm{~K}$, with $\mathrm{CH}_{4}$ rising to $0.01 \mathrm{vol} \%$ and that of oxidizing $\mathrm{CO}_{2}$ not exceeding $2.46 \mathrm{vol} \%$ and steam $\left(\mathrm{H}_{2} \mathrm{O}\right)-3.72 \mathrm{vol} \%$. On further increase in temperature, the volume of syngas almost keeps constant, which is similar to the trend in the abovementioned pyrolysis process. At temperatures above $2150 \mathrm{~K}$, compounds of calcium, phosphorus, and sulfur appeared in the gaseous phase. In the case of processing wet bony tissue, the trend was similar, but only the concentrations and appearance temperature of gas compositions varied. It was seen that carbon is entirely converted into a gaseous phase at a temperature above $1050 \mathrm{~K}$ for dry BT and at $1600 \mathrm{~K}$ for wet $\mathrm{BT}$, whereas tricalcium phosphate $\left(\mathrm{Ca}_{3} \mathrm{P}_{2} \mathrm{O}_{8}\right)$ is in the condensed phase up to the temperature of $3000 \mathrm{~K}$ for both cases. Calcium oxide $(\mathrm{CaO})$ also preserves

Table 4 The influences of temperature and steam on the gaseous products in a plasma gasification numerical simulation [68]

\begin{tabular}{|c|c|c|c|c|c|c|c|c|c|c|c|c|c|c|c|}
\hline & & $\mathrm{CO}$ & $\mathrm{H}_{2}$ & $\mathrm{CH}_{4}$ & \multicolumn{2}{|c|}{$\mathrm{CO}_{2}$} & $\mathrm{H}_{2} \mathrm{O}$ & $\mathrm{PO}$ & $\mathrm{PO}_{2}$ & $\mathrm{P}$ & $\mathrm{Ca}$ & \multicolumn{2}{|c|}{$\mathrm{CaOH}$} & $\mathrm{CaO}_{2} \mathrm{H}_{2}$ & $\mathrm{C}$ \\
\hline \multicolumn{2}{|c|}{ Temp. (K) } & 1300 & & & & & & 3000 & & & & & & & 1500 \\
\hline \multirow[t]{2}{*}{ Dry BT } & & 28.7 & 24.7 & - & \multicolumn{2}{|c|}{$\leq 2.46$} & 3.72 & 0.52 & 0.02 & 0.01 & 1.49 & 0. & 51 & 0.17 & 0 \\
\hline & $\mathrm{CO}$ & $\mathrm{H}_{2}$ & $\mathrm{CH}_{4}$ & $\mathrm{CO}_{2}$ & $\mathrm{H}_{2} \mathrm{O}$ & $\mathrm{PO}$ & $\mathrm{PO}_{2}$ & $\mathrm{P}$ & PS & $\mathrm{P}_{2} \mathrm{O}_{3}$ & $\mathrm{P}_{2}$ & $\mathrm{Ca}$ & $\mathrm{CaOH}$ & $\mathrm{CaOH}_{2}$ & $\mathrm{C}$ \\
\hline $\begin{array}{c}\text { Temp. } \\
\text { (K) }\end{array}$ & 1300 & & & & & 3000 & & 2850 & 2750 & 2350 & 2150 & 3000 & & & 1600 \\
\hline \multirow[t]{2}{*}{ Wet BT } & 38.1 & 46.8 & 0.2 & $\leq 0.25$ & & 2.14 & 0.04 & 0.13 & 0.22 & 19.18 & 0.56 & 1.2 & 0.69 & 0.12 & 0 \\
\hline & $\mathrm{CO}$ & $\mathrm{H}_{2}$ & $\mathrm{CH}_{4}$ & $\mathrm{CO}_{2}$ & $\mathrm{H}_{2} \mathrm{O}$ & $\mathrm{CO}$ & $\mathrm{H}_{2}$ & $\mathrm{CH}_{4}$ & $\mathrm{~N}_{2}$ & $\mathrm{HCl}$ & $\mathrm{H}_{2} \mathrm{~S}$ & & $\mathrm{CaCl}_{2}$ & $\mathrm{SiO}$ & $\mathrm{Cl}$ \\
\hline $\begin{array}{c}\text { Temp. } \\
\text { (K) }\end{array}$ & 1600 & & $\sim 500$ & 1600 & & 3000 & & 1500 & $\begin{array}{r}1200- \\
1300\end{array}$ & $0-3000$ & $\geq 19$ & & & 1600 & \\
\hline $\begin{array}{l}\text { HW } \\
\text { with } \\
\text { air }\end{array}$ & 31.7 & 50.9 & $\sim 15$ & $\leq 0.13$ & & 10.3 & & 0 & 15.5 & $1.2-1.6$ & $\mathrm{~S}, \mathrm{H}$ & & & $<1$ & \\
\hline $\begin{array}{l}\text { HW } \\
\text { with } \\
\text { steam }\end{array}$ & 33.6 & 60.8 & $\sim 15$ & $\leq 0.13$ & & 11.3 & & 0 & 3.5 & $1.2-1.6$ & $\mathrm{~S}, \mathrm{H}$ & & & $<1$ & \\
\hline
\end{tabular}

All gas compositions are expressed with volume fraction

$B T$ bony tissue, $H W$ household waste from healthcare facilities

$* \mathrm{H}_{2} \mathrm{~S}$ dissociates and yields $\mathrm{S}, \mathrm{H}$ 


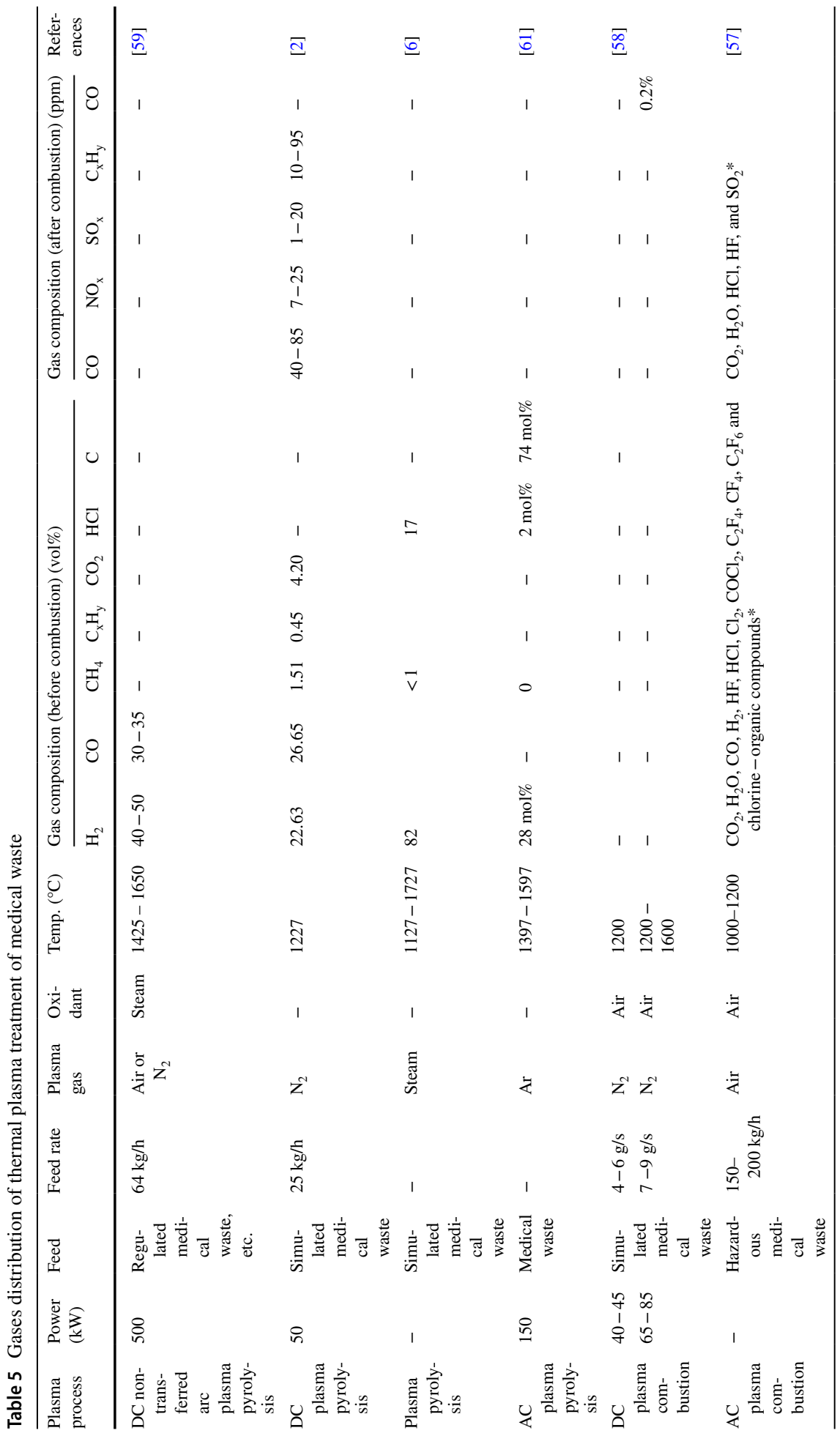




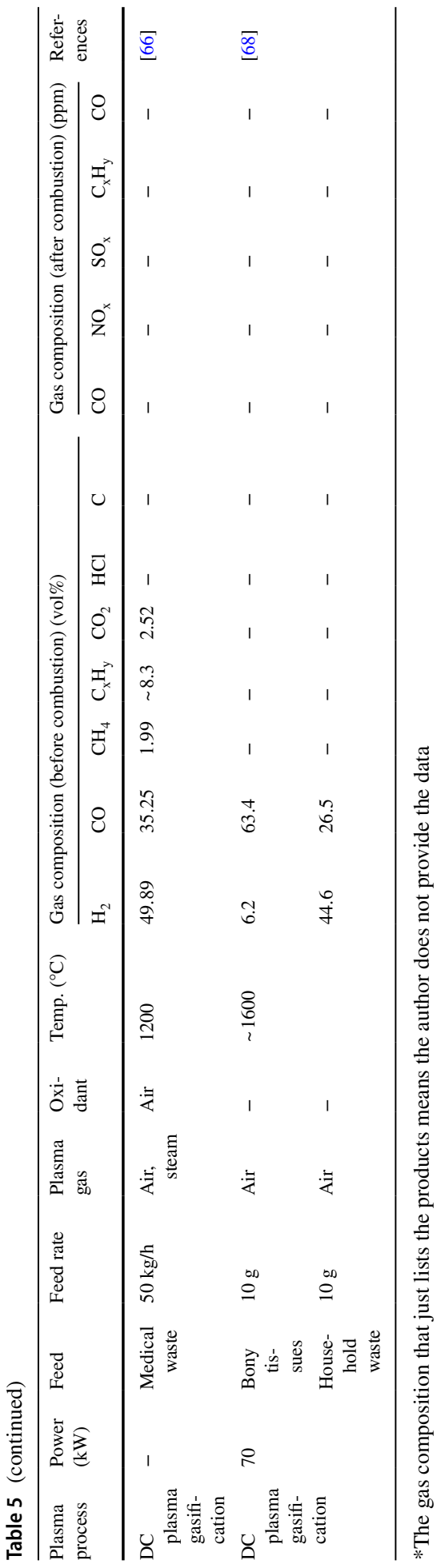


the condensed phase up to $\mathrm{T}=3000 \mathrm{~K}$. Calcium sulfide $(\mathrm{CaS})$ remains in the condensed state up to $\mathrm{T}=2350 \mathrm{~K}$ for dry BT and $2700 \mathrm{~K}$ for wet BT. As for the case of household waste from healthcare facilities (HW), with an increase in temperature, the syngas concentration increases to a maximum value at $\mathrm{T}=1600 \mathrm{~K}$ no matter with air or steam as plasma gas. When the temperature increases to $3000 \mathrm{~K}$, the syngas decreases and reaches $10.3 \%$ and $11.3 \%$ in air and steam gasification of the waste, respectively. Besides, in the air and steam HW gasification, the carbon completely converts into the gas phase at temperatures above $1500 \mathrm{~K}$ and forms $\mathrm{CO}$. In the temperature range from 1200 to $2200 \mathrm{~K}$, the $\mathrm{HW}$ mineral part mainly consists of involves silicon dioxide $\left(\mathrm{SiO}_{2}\right)$, calcium monosilicate $\left(\mathrm{CaSiO}_{3}\right)$, ferric carbide $\left(\mathrm{Fe}_{3} \mathrm{C}\right)$, and iron. At temperatures above $2150 \mathrm{~K}$, the $\mathrm{HW}$ mineral components completely convert into the gas phase, forming certain gaseous compounds.

High temperature also causes more heavy metals volatilization when it is above the boiling point of metals. One of the advantages of thermal plasma technology is that the vitrified slag traps the metals and reduce the amount of metals escaping into the gas phase, but it does not mean traping all of them. In the case conducted by Park et al. [58], the lowest-melting-point metals, such as $\mathrm{Zn}$ and $\mathrm{Pb}$, can be filtered from the gas. Generally, their amount is small and can be removed through the gas cleaning system, thus their concentration in the off-gases discharged into the atmosphere easily meet the regulations.

\section{The Influence of Reactor Environment}

Various plasma gases are used in plasma waste treatment systems, such as air, nitrogen, argon, steam, or carbon dioxide. They and other injected gases jointly create the reaction environment in the plasma reactor, which acts as one of the important reacting substances or affects the mass transfer and heat transfer. One of the differences between plasma pyrolysis and plasma gasification is that the former works in a theoretically oxygen-starved or inert environment.

The steam in the reactor may contribute to the production of $\mathrm{H}_{2}$ in the plasma pyrolysis. Tang et al. [23] found that the sum of $\mathrm{H}_{2}$ and $\mathrm{CO}$ concentrations reached up to about $40 \%$ with water steam injection, while only $15 \%$ was achieved without steam in the plasma pyrolysis of polypropylene. Besides, the addition of steam restricts the formation of soot when oxygen is deficient $[2,57]$. A possible reason is that the $\mathrm{H}_{2} \mathrm{O}$ molecule reacts with soot particles and produces $\mathrm{CH}_{4}$ and $\mathrm{CO}$ [2]. The PEPS process also sets a steam generator to enhance the production of product gas. All these are related to the steam reforming that promotes the generation of syngas, especially for $\mathrm{H}_{2}$. The most typical condition for nitrogen (or other inert gas) plasma pyrolysis is the absence of an oxidizing region, and that is directly transferred to the region of the reduction process. Steam injection gives the pyrolysis an oxidizing region and elevates the carbon conversion and decreases the total energy consumption. $\mathrm{N}_{2}$ and air usually act as plasma gas in the thermal plasma treatment. If $\mathrm{N}_{2}$ and $\mathrm{O}_{2}$ exist in the reactor, the problem of $\mathrm{NO}_{\mathrm{x}}$ formation may occur $[99,100]$. In general, lower temperatures have a positive effect on $\mathrm{NO}_{\mathrm{x}}$ reduction [100]. Another approach to avoid the formation of $\mathrm{NO}_{\mathrm{x}}$ is to employ non-nitrogen-containing plasma gas. In a plasma steam gasification, the lack of nitrogen in the gasification agent solves the problem of nitrogen oxides [66]. Therefore, the steam plasma pyrolysis or gasification of medical waste may solve this problem. Besides, Sheng et al. [60] investigated the case that $\mathrm{H}_{2}$ as plasma gas, there was no generation of $\mathrm{NO}_{\mathrm{x}}$ and other hazardous organic components.

A similar phenomenon of the addition of steam occurs in the plasma gasification of biomedical waste [68]. In the numerical simulation study, comparing the plasma gasification 
processing of dry and wet bony tissue, the syngas reached $53.4 \mathrm{vol} \%$ (28.7 vol\% of CO, $24.7 \mathrm{vol} \%$ of $\mathrm{H}_{2}$ ) and $84.9 \mathrm{vol} \%\left(38.1 \mathrm{vol} \%\right.$ of $\mathrm{CO}, 46.8 \mathrm{vol} \%$ of $\mathrm{H}_{2}$ ) at $1300 \mathrm{~K}$ respectively. Meanwhile, the condensed components did not change but their conversion temperature. The results revealed that the addition of steam to the system does not cause a qualitative change in the behavior of the main components of the gaseous and condensed phases and only affects the concentration of hydrogen in the syngas. Besides, the heat of combustion obtained through BT air gasification amounts to $3510 \mathrm{~kJ} / \mathrm{kg}$, and the heat of combustion obtained through BT steam gasification is $5664 \mathrm{~kJ} / \mathrm{kg}$. As expected in the case of processing $\mathrm{HW}$, the maximum syngas concentration reaches $82.6 \%\left(\mathrm{CO}-31.7 \%, \mathrm{H}_{2}-50.9 \%\right)$ in the air gasification, and in the steam gasification, it is as high as $94.4 \%(\mathrm{CO}-33.6 \%$, $\mathrm{H}_{2}-60.8 \%$ ). From Table 4, it is seen that the syngas concentration in steam gasification is $11.8 \%$ higher, and the ballast-nitrogen concentration is $12 \%$ lower than in the case of air gasification. Meanwhile, air gasification of HW gives the heat of combustion of the syngas equal to $13,620 \mathrm{~kJ} / \mathrm{kg}$, whereas steam gasification of $\mathrm{HW}$ gives $18,497 \mathrm{~kJ} / \mathrm{kg}$. This reveals that plasma gasification of medical waste has great potential for electricity production by utilizing the combustible gas, for example, using gas-turbine plants and gas-powered electrical generators. Besides, additional oxidants, such as oxygen and air, interact with the plasma gas in the plasma combustion process. This injection aims to generate intense mixing and heating-up, which is the basic requirement for an intensive process flow [5]. However, in the gasification process, Oxygen adding increases the overall energy consumption and decreases the yield of the syngas due to the oxidation reaction [66].

\section{The Influence of Feed Rate and Residence Time}

The Plasma Application and Research Facility (PARF) has developed a plasma technology to treat medical waste, municipal solid waste and contaminated soil (see Fig. 12) [93]. The feed rate is also an important parameter to affect the gas yield. When the feed rate is lower, there was more residence time to be processed for the waste, thus the higher heating value of combustible gas was obtained. In the study of Tang et al. [23], the polypropylene was feeded with the range of 20-100 g/min. It was observed that the $\mathrm{H}_{2}$ and $\mathrm{C}_{2} \mathrm{H}_{2}$ concentrations were increased as the feed rate was increased. The possible reason is that the concentration of hydrogen and carbon in the system is increased while the carrier gas is kept unchanged. On the other hand, increasing the feed rate may decrease the amount of energy available to heat each particle and likely decrease the average reaction temperature, leading to a lower solid conversion percentage. This phenomenon may reduce the higher heating value of combustible gas according to the conclusion obtained by Vaidyanathan et al. [93]. The longer residence time of the feedstock in the plasma furnace results from the lower feed rate, other reasons such as furnace design are rarely investigated [93]. Generally speaking, the residence time of solid waste in the plasma furnace is closely related to treatment performance. The longer the residence time, the better the treatment performance, which is common law in thermal treatment processes.

Some process parameters that influence gas production are given, but it cannot include all the influence parameters. For example, the reactor configuration, the reactor shape, particle size (when the feedstock is powdered), etc. also play roles in affecting the gas output. Table 5 presents the gases distribution of various thermal plasma treatment of medical waste. The production of high-content syngas reveals that energy recovery should be paid attention to the thermal plasma treatment of medical waste. 


\section{Solid Products}

The solid products are obtained in the forms of slag, ashes, and particles in the gas phase. The formation process of slag includes the following stage: the incineration of combustible components, melting and mixing of inorganic components, and separation of slag and metals [89]. The vitrification process in plasma combustion, pyrolysis, and gasification may be different to some extent owing to the discrepancy among the process parameters. The acquisition of slag products effectively prevents secondary pollution from the bottom products. Some TCLP test results from thermal plasma treatment are shown in Table 6 [59, 67, 89]. It can be seen the produced slags exhibit low toxicity levels that comply with the regulatory limits of China and the USA. By virtue of the inert characteristics, these vitrified products may be used in the manufacture of architectural tiles and construction materials, or landfill as non-hazardous wastes.

\section{The Influence of Feeding Method}

The method of waste packing is also important for the combustion of solid residual. In Park et al.'s experiments [58], when the waste was fed into furnace in cloth bags, the cloth burnt up at once, and large remainders and ashes remained from burning were scattered along the path of the plant. However, when in glass cloth or board boxes, thermal destruction occurred without nitrogen removal in the form of ashes and soot, and with a slight carry-over of ash and other volatile components. Besides, the feedstock can be briquetted or powdered before the plasma reactor. These feeding methods are expected to greatly influence the solid residual production, but rare studies are reported in investigating these parameters.

Table 6 TCLP test results of heavy metals in the vitrified slag derived from medical waste

\begin{tabular}{|c|c|c|c|c|c|}
\hline \multirow[t]{2}{*}{ Heavy metals } & \multicolumn{5}{|c|}{ Thermal plasma treatment processes } \\
\hline & $\begin{array}{l}\text { Plasma pyroly- } \\
\text { sis (mg/L) [59] }\end{array}$ & $\begin{array}{l}\text { Plasma gasifica- } \\
\text { tion }(\mathrm{mg} / \mathrm{L})[67]\end{array}$ & $\begin{array}{l}\text { Plasma vitrifica- } \\
\text { tion }(\mathrm{mg} / \mathrm{L})[89]\end{array}$ & $\begin{array}{l}\text { China } \\
\text { standard } \\
{[101]}\end{array}$ & $\begin{array}{l}\text { USA } \\
\text { standard } \\
{[102]}\end{array}$ \\
\hline Arsenic & 0.20 & $\mathrm{ND}<0.026$ & - & 5 & 5 \\
\hline Barium & - & 0.797 & - & 100 & 100 \\
\hline Cadmium & 0.14 & $\mathrm{ND}<0.007$ & - & 1 & 1 \\
\hline Total chromium & 0.72 & 0.173 & - & 15 & 5 \\
\hline Copper & - & $0.100(0.015)$ & $0.27-2.1$ & 100 & - \\
\hline Hexavalent chromium & - & $\mathrm{ND}<0.01$ & - & 5 & - \\
\hline Lead & 0.73 & ND 0.014 & - & 5 & 5 \\
\hline Mercury & 0.02 & $\mathrm{ND}<0.0005$ & - & 0.1 & 0.2 \\
\hline Nickel & - & 0.121 & - & 5 & - \\
\hline Selenium & 0.50 & $\mathrm{ND}<0.024$ & - & 1 & 1 \\
\hline Silver & 0.10 & $\mathrm{ND}<0.006$ & - & 5 & 5 \\
\hline Zinc & - & 0.378 & $0.091-0.65$ & 100 & - \\
\hline
\end{tabular}

$N D$ not detectable with limit in parentheses 


\section{The Influence of Feed Composition}

The feed composition will significantly affect the performance of plasma vitrification. In a plasma vitrification process with medical waste, different raw materials ratios (stainless steel:glass: pork rib in weight) were performed to identify the slag properties and TCLP results [89]. The obtained slag exhibited the amorphous nature no matter pulverize or not. When the feed contained fewer metals, very few second phases were observed through the BEI mode of SEM. By contrast, feed composition with higher metals results in more formation of various second phases dispersed in the glassy slag [89]. Spheroids, plate (or needle), and irregular-shaped phases are mainly second phases. During the vitrification process, metal elements formed alloys or compounds that were not soluble, resulting in spheroids and other shaped phases in the slag matrix. Among them, spheroids are Fe-rich and irregular and plate-shapes phases are Cr-rich, which is caused by high-temperature driven diffusion effects. Then these ellipsoidal metal nugget separated from the glassy slag due to the gravity effect during the treatment. The results showed that the plasma vitrification can ensure mixing and achieve a homogenous state of vitrified slag during the treatment. Besides, the results of slag densities revealed no considerable variations with the feed $\left(2.60-2.94 \mathrm{~g} / \mathrm{cm}^{3}\right)$, but they seem to be higher as the glass in the feed decreased, the steel in the feed increased and the increased metallic-bearing phases. The results of the TCPL test showed that $\mathrm{Cr}$ and $\mathrm{Zn}$ exhibited insignificant leachability characteristics, which means the encapsulation of insoluble metal-bearing second phase by the slag matrix occurred effectively. It was proposed that the optimal feed combinations determined in this study were those with the metallic components less than $40 \%$ of feed in weight. Because too high metal components result in high volume fractions of second phases and the incomplete vitrification of additive $(\mathrm{ZnO})$, thus lead to high $\mathrm{Cr}$ and $\mathrm{Zn}$ concentrations in the leachate.

Zhang et al. [103] investigated the plasma vitrification of simulated medical wastes in China with different feed compositions. Two samples performed in the study are listed in Table 7. The obtained slag exhibited a typical glassy, dense structure, and smooth surface. The density of slag derived from $\mathrm{SWM}_{1 / 4}$ and $\mathrm{SWM}_{1 / 5}$ were $2.60 \mathrm{~g} / \mathrm{cm}^{3}$ and 2.52 respectively, similar to those reported by Chu et al. [89]. Besides, it was found that the mechanical properties of vitrified slag are also similar to soda-lime-silica glass. Most heavy metals were solidified in the slags with a solidifying rate of $68.5-89.4 \%$. The results of heavy metals in the slag manifested $\mathrm{Ni}$ and $\mathrm{Cr}$ has higher concentration and leaching, but all heavy metals had a value below the leaching limit in China.

\section{The Influence of Additives and Co-treatment}

In the abovementioned study [89], $\mathrm{ZnO}$ was added to the feed as a tracer metal prior to treatment. In case of AC plasma pyrolysis [60], $\mathrm{CaO}$ and $\mathrm{SO}_{2}$ were mixed to obtain vitrified slag. However, little literature on investigating the effects of the additive of medical

Table 7 The composition of simulated medical wastes in a plasma vitrification process (wt\%) [103]

\begin{tabular}{llllllll}
\hline Composition & $\begin{array}{l}\text { Rubber and } \\
\text { plastic }\end{array}$ & Fabric & Paper & $\begin{array}{l}\text { Cotton } \\
\text { bamboo }\end{array}$ & Glass & Steel & Others \\
\hline $\mathrm{SMW}_{1 / 4}$ & 50 & 17 & 5 & 5 & 14.5 & 3.6 & 5 \\
$\mathrm{SMW}_{1 / 5}$ & 50 & 17 & 5 & 5 & 15 & 3 & 5 \\
\hline
\end{tabular}


waste plasma treatment is published. Li et al. [61] investigated the effects of some additives on the vitrified slag, Table 8 shows three different mixtures of wastes and their results after plasma pyrolysis treatment. The destruction and removal efficiency of chemical waste is more than $99.999 \%$. The solid residues contain PCBs in the range of $1.28-12.9 \mathrm{mg} / \mathrm{kg}$, which is far below the Chinese national emission limit value for hazardous wastes. The results showed these additives have an effective enhancement in forming vitrified slag. However, some of the vitrified slag produced in the experiments is not dense and mat. This may be caused by additives with an inappropriate proportion. Therefore, in order to obtain slags for utilization, it is needed to optimize the addition of additives.

For other hazardous wastes, $\mathrm{SiO}_{2}$ content has been proven to enhance the plasma vitrification process $[40,98,104]$. It can result in the domination of $\mathrm{SiO}_{4}$ tetrahedron inside the vitrified slag, and thus traps metals [105]. Also, the hardness of the slag is improved when $\mathrm{SiO}_{2}$ in the feed is higher [106]. In a case of plasma vitrification of medical waste incineration ash, the addition of $15 \% \mathrm{SiO}_{2}$ was claimed to increase the stability of produced vitrificate. In other thermal treatments, for example, the treatment of fly ashes from a medical waste incinerator, $\mathrm{CaO}$ was proven to reduce the PCDD/F content at a low temperature $\left(250{ }^{\circ} \mathrm{C}\right)$. Therefore, the selection of additives (or waste type to be co-treated) and the optimization of leachability and hardness of solid product should be noticeable for their utilization and cost reduction.

\section{The Influence of Temperature}

Temperature plays a significant role in the formation of slag and the behavior of melted slag during the process. When furnace temperature did not exceed $1250-1300{ }^{\circ} \mathrm{C}$ (operated at $40-45 \mathrm{~kW}$ ), the formed melt had a high viscosity and did not flow out of the bath [58]. In contrast, when this temperature exceeded $1500{ }^{\circ} \mathrm{C}$ (operated at $65-85 \mathrm{~kW}$ ), all accumulated vitreous compounds could flow with the density of $2.6-2.8 \mathrm{~g} / \mathrm{sm}^{3}$. The formed slag has fine cavities on its surface with a brown color and inclusions of dull grey and shining colors. In this study, the distance between plasma torch and bath has less enhancement because the former case is 25-30 sm while the latter case is 40-45 sm. Another solid product is metal particles collected by a filter. A piece of pioneer literature claimed that above $900{ }^{\circ} \mathrm{C}$, the ash begins to melt in the presence of oxygen when biomedical waste was applied to the plasma pyrolysis [107]. However, high temperature also means more heavy metals will volatilize to the gas phase. A number of studies have reported the volatilization

Table 8 Mixtures of chemical wastes after treatment by the three-phase AC plasma reactor [61]

\begin{tabular}{|c|c|c|c|c|c|c|c|c|c|}
\hline \multirow[t]{2}{*}{ Sample } & \multicolumn{2}{|c|}{$\begin{array}{l}\text { Chemical } \\
\text { wastes }(\mathrm{g})\end{array}$} & \multicolumn{3}{|c|}{ Additives (g) } & \multicolumn{4}{|c|}{ The composition of solid residue } \\
\hline & CW-1 & $\mathrm{CW}-2$ & $\mathrm{SiO}_{2}$ & $\mathrm{C}$ & $\mathrm{CaO}$ & $\begin{array}{l}\text { Chlorobiphe- } \\
\text { nyl }\end{array}$ & $\begin{array}{l}\text { Dichlorobi- } \\
\text { phenyl }\end{array}$ & $\begin{array}{l}\text { Trichlorobi- } \\
\text { phenyl }\end{array}$ & Total PCBs \\
\hline Mixture 1 & 100 & & & 100 & 300 & 1.26 & 0.0217 & ND & 1.28 \\
\hline Mixture 2 & & 150 & 120 & & 150 & 12.8 & 0.122 & 0.0131 & 12.9 \\
\hline Mixture 3 & 20 & 20 & 15 & & 5 & - & - & - & - \\
\hline
\end{tabular}

CW-1: biphenyl, 80-85 wt \%; PCBs, 10-15 wt $\%$, CW-2: silicon powder, $60 \mathrm{wt} \%$; copper powder, $2 \mathrm{wt} \%$; carbon compounds, 25-30 wt \%; Unknown organics, 10 wt \%

$N D$ not detected 
of heavy metals in plasma treatment of various waste streams [40, 108-110]. Although the percentage of metals in medical waste may be lower, it can not be neglected.

The solid products from thermal plasma are characterized by lower metals leaching and inertness. Feeding method, feed composition, temperature, and additives play roles in the formation of slags using thermal plasma treatment of medical waste. Other influence parameters may also include the reactor environment, reactor type, reactor pressure, etc. Table 9 lists some parameters and the obtained slag during various thermal plasma treatment of medical waste.

\section{Mass/Volume Reduction and Pathogen Destruction}

In general, the more organic matter the feedstock, the higher the mass and volume reductions. According to Nema et al. [2], plasma pyrolysis can reduce the volume of organic matter with more than $99 \%$. The PEPS process can reduce the waste volume by a factor of 110 , and its mass by a factor of 10, and the residue exhibits inert characteristic [59]. In the plasma gasification plant in Shanghai, a mass reduction over 5-to-1 and volume reductions over 23-to-1 were achieved as $1228 \mathrm{~kg}$ of waste and additives were processed and only $236 \mathrm{~kg}$ of vitrified material remained [67]. The large reduction of solid residual ensures the reduction of landfill disposal. In the two-stage plasma combustion of hazardous medical waste, the volume of the waste remaining for burial decreases by 50-400 times [57]. The significant reduction in waste mass and volume occurs during thermal plasma treatment of medical waste, which is essential in the management of medical waste.

Although rare studies directly investigate the effect of thermal plasma on pathogen destruction, the high temperature and plasma active species contribute to this effect without a doubt. In plasma pyrolysis of medical waste conducted by Nema et al. [2], it was observed that B. subtilis and B. stearothermophilus pathogens (spores) were destroyed because high temperature degrades the DNA molecule of the cell. In practice, the average temperatures of thermal plasma processes range from 1000 to $2000{ }^{\circ} \mathrm{C}$, which plays the leading roles in pathogen destruction. There are electrons, ions, neutral particles, free radicals and other active species as well as the emission of ultraviolet (UV), visible and nearinfrared radiations in the plasma. In addition to the benefit of high temperature, the effects of these reactive species in plasma should never be ignored. In the biological applications of plasma (e.g. plasma medicine, the disinfection of foods and agricultural products, etc.), studies undertaken have generally focused on non-thermal plasma usually maintained near room temperature for destroying microorganisms and spores. These microorganisms can be bacteria, fungi, virus, and prions, etc. [111], which shows the great adaptation of plasma to various pathogens. Although non-thermal plasma has a lower degree of ionization and energy densities, it will help us better understand the mechanisms that affect pathogen destruction. Etching action caused by electrons and ions fastly damages the cell membrane and its repair capability. Oxidative effects by free radical species significantly degrade various substances such as lipids, proteins, and DNA. The role of UV photons is controversial since their production depends on the discharge type and plasma gas in use. Some studies found its ability to cleave DNA while some studies claimed UV was not effective at specific discharge type and wavelength of the radiation, etc. [112, 113]. In addition, electrostatic disruption and electroporation are possible physical mechanisms to explain the antimicrobial effects [114]. The abovementioned mechanisms significantly depend on the type of plasma gas (or rection atmosphere). A review conducted by Sakudo et al. [115] believed that reactive chemical species, UV radiation, and electric fields contribute to the 


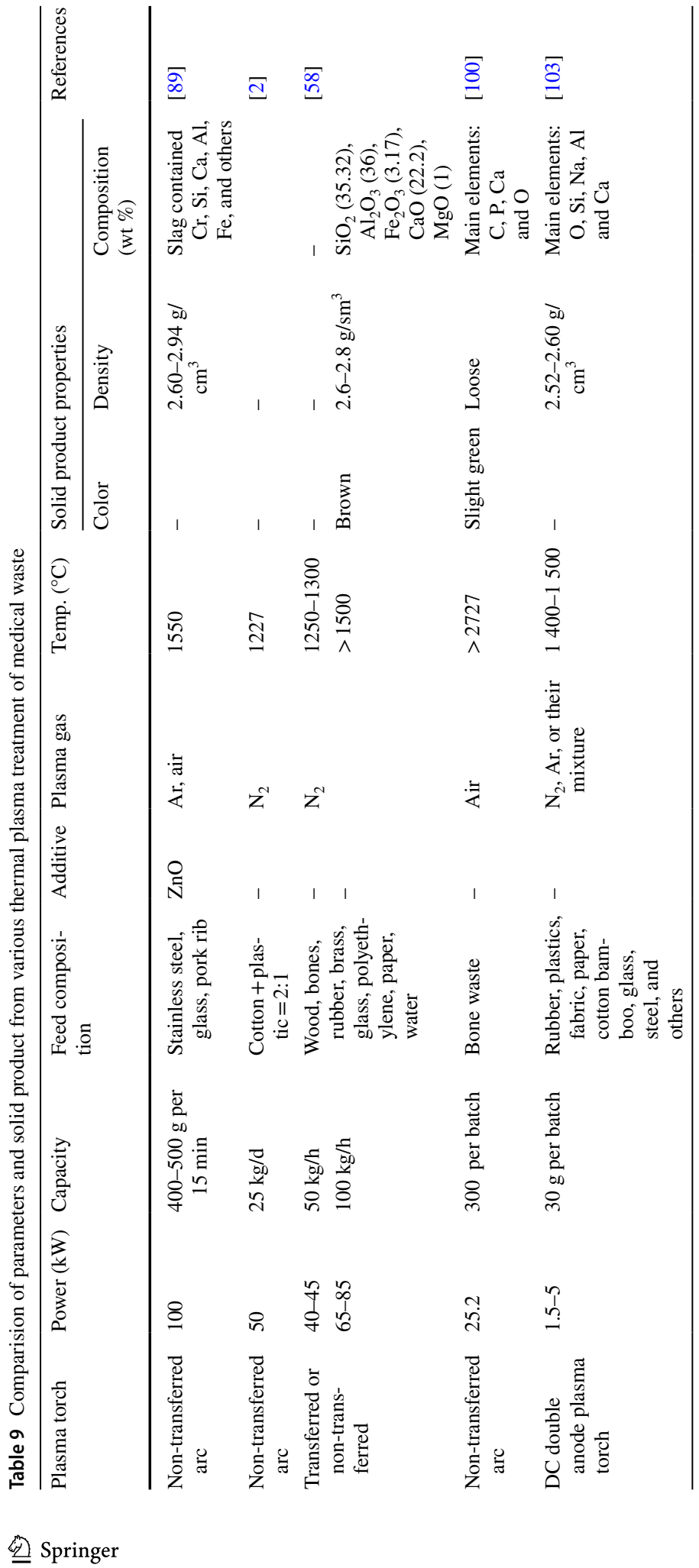




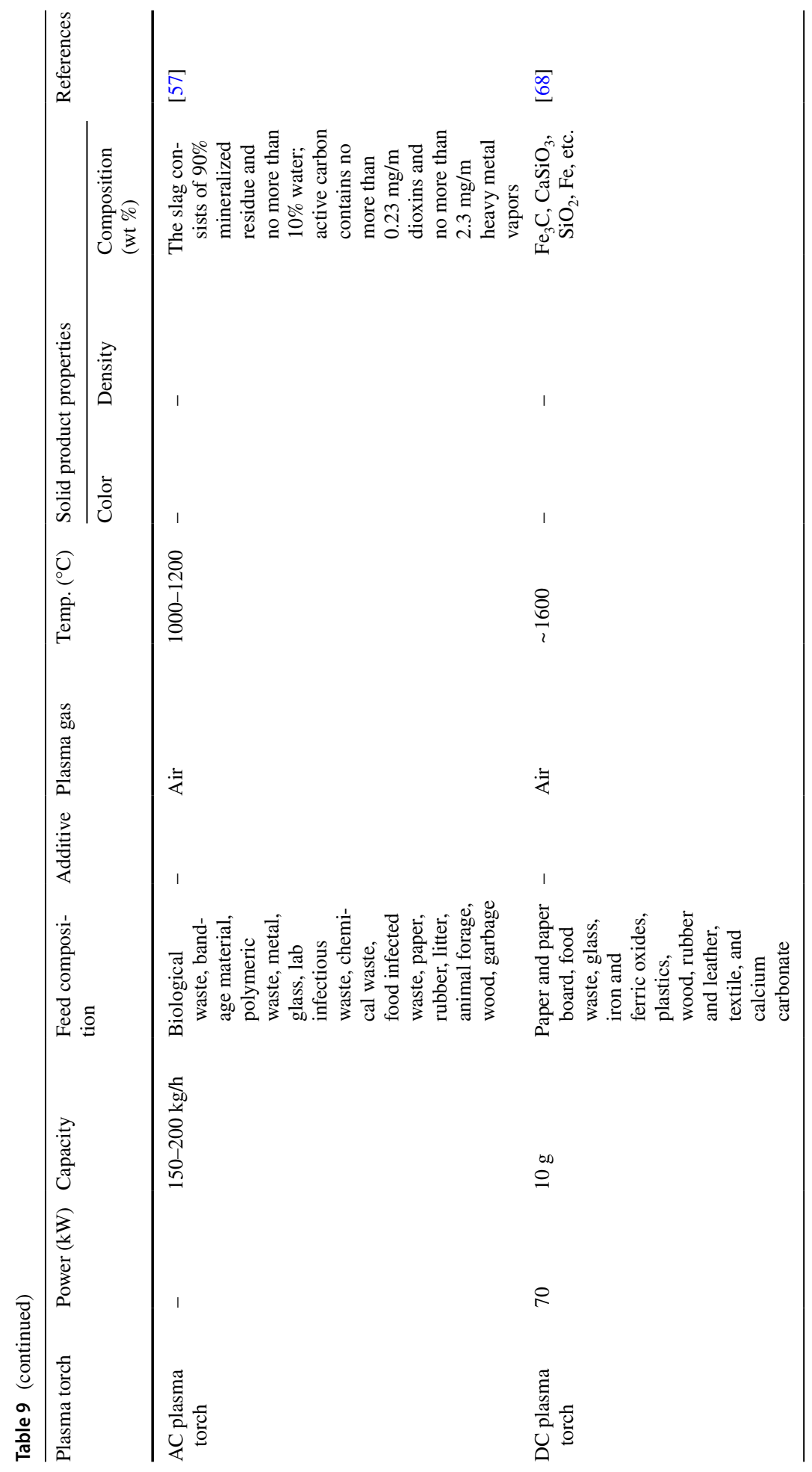


microbicidal properties of the non-thermal plasma. In thermal plasma, the production and type of particle species also depend on the type of plasma torch and plasma gas, and temperature, etc. It is reasonable to deduce that these factors also influence the inactivation and destruction performance of various pathogens. Thermal plasma treatment of medical waste still lacks enough knowledge of pathogen destruction, and there is therefore a need for more investigation.

\section{Energy Recovery}

It provides one of the most economically sustainable long-term alternatives to medical waste destruction when combined with energy recovery equipment especially with a tendency that the plastics content of the medical waste is increasing in modern society. There are two ways to recover energy: energy from combustible gas and heat from flue gas. The heat from flue gas is achieved by using a conventional heat exchanger. The syngas may be used to generate electricity or heat and produce valuable chemical agents (i.e. hydrocarbonic acids, hydrogen) [116].

Plasma pyrolysis of organic waste provides a large quantity of $\mathrm{CO}$ and $\mathrm{H}_{2}$ gases as byproducts. In the case carried out by Nema et al. [2], the recovered energy from combustible gas can reduce the operational cost by $38.5 \%$. The combustion of $\mathrm{CO}$ and $\mathrm{H}_{2}$ gases contribute to the release of energy that one $\mathrm{g}$-mol $\mathrm{CO}$ and one g-mol $\mathrm{H}_{2}$ generate $125.45 \mathrm{kcal}$ energy at the rate of $25 \mathrm{~kg} / \mathrm{h}$. The volume of $\mathrm{CO}_{2}$ and $\mathrm{H}_{2}$ from medical waste was more than $49 \mathrm{vol} \%$. Whereas pure plastic can provides more than $90 \%$ combustible gases after the treatment [2]. This means medical waste has a great potential for energy utilization as plastics material is increasingly used in the modern medical industry.

In the plasma gasification conducted by Messerle et al. [68], the main portion of the generated energy is the heat value of the produced fuel gas (68\%) while the sensible heat of the gas is $19 \% .52 \%$ of the incoming energy is the electrical energy supplied by the plasmatron. The biomedical waste plasma gasification process is characterized by a high overall thermal efficiency of $86.5 \%$. In this study, the fuel gas is produced having a calorific value of $337.6 \mathrm{MJ} / \mathrm{h}$ and a sensible heat of $92.4 \mathrm{MJ} / \mathrm{h}$.

However, this topic still needs further investigation as the composition of medical waste is complicated. There are several factors that affect the recovery of energy or material in a thermal plasma plant for medical waste treatment. In previous investigations, most of the feedstock are simulated or only contain several typical compositions. Although thermal plasma methods have good feedstock adaptability, it is necessary to keep stable feedstock and sufficient capacity when the plant is scaled up since this influences the product range and sufficient energy recovery. Meanwhile, the utilization method of syngas and other waste heat should be considered including the purification, conversion, and storage of syngas. Besides, whether the product gas is competitive on the market should be not ignored.

\section{Mechanism of Thermal Treatment of Medical Waste}

As mentioned in "Typical Thermal Plasma Processes for Treating Medical Waste" section, four main thermal plasma processes are classified, which depend on various chemical reactions that distinguish them. Notably, reaction pathways are usually combined in each process due to the multi-component property of medical waste and the variation of operational parameters. In a plasma process, the reactions are not only driven by thermal chemistry but 
also plasma chemistry. The plasma discharge generates various active species depending on the types of working gas. Some plasma gases and their generated species participate in the chemical reactions, and some do not. In thermal plasma treatment of medical waste, air, $\mathrm{N}_{2}$ and $\mathrm{Ar}$ are mostly used. Figure 14 describes a simplified schematic representation of the major products of four basic thermal plasma processes.

In the thermal plasma combustion process, combustion reactions occur in the presence of excess oxygen, in which carbonaceous substances are oxidized to produce $\mathrm{CO}_{2}$ and $\mathrm{H}_{2} \mathrm{O}$. For instance, polyethylene is commonly used as one of the simulated medical waste composition, its oxidation can be expressed by the following equation:

$$
\left(\mathrm{CH}_{2} \mathrm{CH}_{2}\right) n+3 n \mathrm{O}_{2} \rightarrow 2 n \mathrm{CO}_{2}+2 n \mathrm{H}_{2} \mathrm{O}
$$

However, if the air is insufficient, the following Eqs. (2)-(4) also occur to produce CO and/or $\mathrm{H}_{2}$.

$$
\begin{gathered}
\mathrm{C}+\frac{1}{2} \mathrm{O}_{2} \rightarrow \mathrm{CO} \\
\mathrm{C}+\mathrm{CO}_{2} \rightarrow 2 \mathrm{CO} \\
\mathrm{C}+\mathrm{H}_{2} \mathrm{O} \leftrightarrow \mathrm{CO}+\mathrm{H}_{2}
\end{gathered}
$$

When steam is introduced to the combustion reaction, it also plays a role in reducing soot formation [2]:

$$
3 \mathrm{C}+2 \mathrm{H}_{2} \mathrm{O} \rightarrow 4 \mathrm{CH}_{4}+2 \mathrm{CO}
$$

One biggest difference between plasma combustion and conventional combustion is that the former process is assumed to the decomposition of the organic part of the wastes and the emission and combustion of the volatiles begin instantly since average temperatures are high enough [58]. These reactions occur in the single plasma reactor,

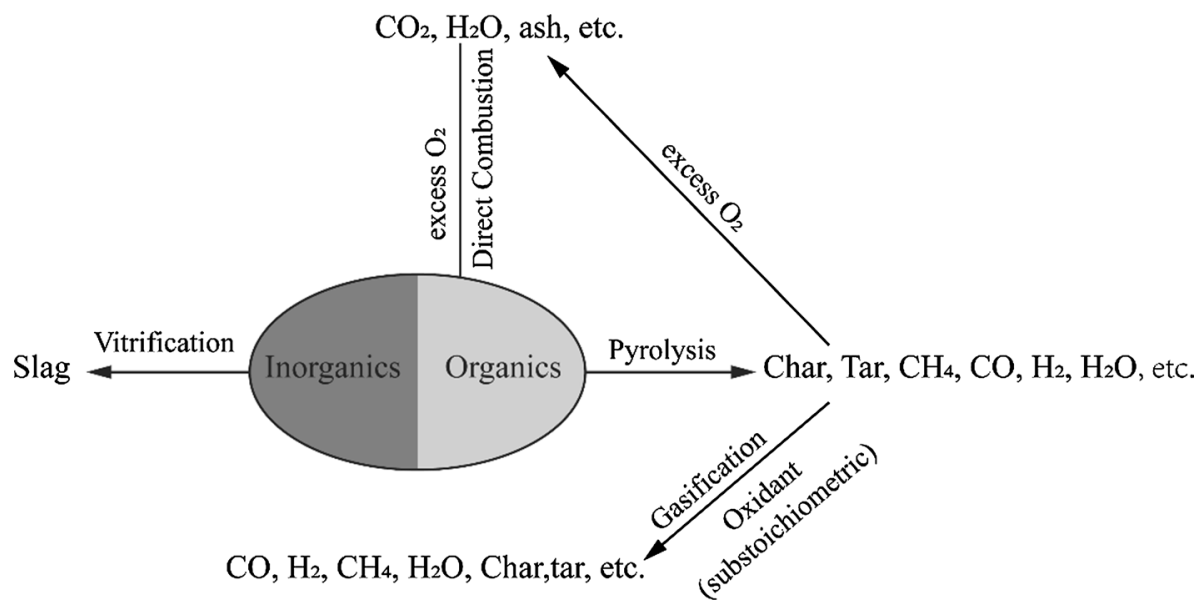

Fig. 14 Simplified schematic representation of the major products of four basic thermal plasma processes 
which is similar to those that occur in the secondary burning chamber of a plasma pyrolysis process [2]. They are the oxidation of combustible components including:

$$
\begin{aligned}
2 \mathrm{CO}+\mathrm{O}_{2} & \rightarrow 2 \mathrm{CO}_{2} \\
2 \mathrm{H}_{2}+\mathrm{O}_{2} & \rightarrow 2 \mathrm{H}_{2} \mathrm{O} \\
\mathrm{C}_{n} \mathrm{H}_{m}+\left(n+\frac{m}{4}\right) \mathrm{O}_{2} & \rightarrow n \mathrm{CO}_{2}+\frac{m}{2} \mathrm{H}_{2} \mathrm{O}
\end{aligned}
$$

In thermal plasma pyrolysis, organics are cracked into smaller molecules that depend on the original waste composition at extremely high temperatures. Free radical reactions are abundant due to the high temperature and plasma species, which enhance the pyrolysis process. Due to the high plastic content in medical waste, possible reactions that take place during plasma pyrolysis are described as following.

Cellulose thermal cracking [2]:

$$
\mathrm{C}_{6} \mathrm{H}_{10} \mathrm{O}_{5}+\text { heat } \rightarrow \mathrm{CH}_{4}+2 \mathrm{CO}+3 \mathrm{H}_{2} \mathrm{O}+3 \mathrm{C}
$$

Polyethylene thermal cracking [2]:

$$
\left[-\mathrm{CH}_{2}-\mathrm{CH}_{2}-\right] n+\mathrm{H}_{2} \mathrm{O}+\text { heat } \rightarrow x \mathrm{CH}_{4}+y \mathrm{H}_{2}+z \mathrm{CO}
$$

Of course, there exist more complex reactions in the plasma pyrolysis, thus leading to various other productions of light and heavy hydrocarbon, char, and tar. Similar to conventional pyrolysis, the plasma pyrolysis reaction that generally is the first stage of other thermochemical conversion processes can be simplified by the following equation $[117,118]$ :

$$
\mathrm{C}_{a} \mathrm{H}_{b} \mathrm{O}_{c} \rightarrow \mathrm{CO}_{2}+\mathrm{H}_{2} \mathrm{O}+\mathrm{CH}_{4}+\mathrm{CO}+\mathrm{H}_{2}+\mathrm{C}_{x} \mathrm{H}_{y}+\mathrm{C}_{m} \mathrm{H}_{n}
$$

where the heavier hydrocarbon fractions (tar, etc.) produced by thermal cracking are represented by $\mathrm{C}_{x} \mathrm{H}_{y}$ and $\mathrm{C}_{n} \mathrm{H}_{m}$ represents hydrocarbons with less carbon atoms and/or greater unsaturation than $\mathrm{C}_{x} \mathrm{H}_{y}$. The secondary cracking of these hydrocarbons will occur at high temperatures. For previous studies, hydrogen-rich syngas and carbon black are the two most important products in the thermal plasma pyrolysis of carbonaceous wastes [25, 119-121]. Other reactions that contribute to the production of syngas also include Eq. (3) (boudouard reaction) and the partial oxidations if limited oxidants exist in the pyrolyzer.

There is a partial overlap that increases with the increased temperature between pyrolysis and gasification [122]. As steam is introduced to the pyrolysis reaction environment, the process seems to act more like a plasma gasification process. Possible reactions related to $\mathrm{H}_{2} \mathrm{O}$ in the plasma pyrolysis include Eq. (4) (water-gas reaction) and the following equations (Eqs. 12-16). Among them, the $\mathrm{C}$ in Eq. (12) can be replaced by CO.

$$
\mathrm{C}+2 \mathrm{H}_{2} \mathrm{O} \leftrightarrow \mathrm{CO}_{2}+2 \mathrm{H}_{2}
$$

Primary water-gas reaction:

$$
\mathrm{C}+\mathrm{H}_{2} \mathrm{O} \leftrightarrow \mathrm{CO}+\mathrm{H}_{2}
$$

Steam reforming $\left(\mathrm{C}_{x} \mathrm{H}_{y}\right.$ can be replaced by $\mathrm{C}_{n} \mathrm{H}_{m}$, the same applies to other reactions related to $\left.\mathrm{C}_{x} \mathrm{H}_{y}\right)[6,45]$ : 


$$
\begin{gathered}
\mathrm{C}_{x} \mathrm{H}_{y}+x \mathrm{H}_{2} \mathrm{O} \leftrightarrow x \mathrm{CO}+\left(x+\frac{y}{2}\right) \mathrm{H}_{2} \\
\mathrm{CH}_{4}+\mathrm{H}_{2} \mathrm{O} \leftrightarrow \mathrm{CO}+3 \mathrm{H}_{2} \\
\mathrm{CH}_{2} \mathrm{CHCl}+2 \mathrm{H}_{2} \mathrm{O} \leftrightarrow 2 \mathrm{CO}+2 \mathrm{H}_{2}+\mathrm{HCl}
\end{gathered}
$$

Thermal plasma gasification is a process in which incomplete oxidation of organics occurs in the presence of oxidants, to produce a combustible gas, which can be regarded as an extension of the pyrolysis process [45]. Therefore, its chemical reactions include almost all aforementioned pyrolysis reactions including reactions correlated with $\mathrm{H}_{2} \mathrm{O}$. Meanwhile, oxidations and partial oxidations of carbon and combustible gases occur due to the existence of oxidants. Several representative reactions are expressed as follow:

$$
\begin{gathered}
\mathrm{C}_{x} \mathrm{H}_{y}+\frac{x}{2} \mathrm{O}_{2} \leftrightarrow \frac{y}{2} \mathrm{H}_{2}+x \mathrm{CO} \\
\mathrm{CO}+\frac{1}{2} \mathrm{O}_{2} \rightarrow \mathrm{CO}_{2} \\
\mathrm{H}_{2}+\frac{1}{2} \mathrm{O}_{2} \rightarrow \mathrm{H}_{2} \mathrm{O}
\end{gathered}
$$

Other important gasification reactions also include:Dry reforming:

$$
\mathrm{C}_{x} \mathrm{H}_{y}+x \mathrm{CO}_{2} \leftrightarrow \frac{x}{2} \mathrm{CO}+\frac{y}{2} \mathrm{H}_{2}
$$

Hydrogasification:

$$
\mathrm{C}+2 \mathrm{H}_{2} \leftrightarrow \mathrm{CH}_{4}
$$

Methanation:

$$
\mathrm{CO}+3 \mathrm{H}_{2} \leftrightarrow \mathrm{CH}_{4}+\mathrm{H}_{2} \mathrm{O}
$$

Generally, only complete oxidation reactions are irreversible. According to the GasifEq thermodynamic equilibrium model developed by Mountouris et al. [123], Eqs. (4), (13) and (15) were selected as independent equilibrium reactions to predict and optimize the plasma gasification, and the prediction was close to the experimental results. All mentioned reactions are simplified and the actual situations depend on the feedstock composition and the operational parameters. Take polymer polyvinyl chloride (PVC) for example, its simplified steam reforming reaction can be expressed by Eq. (23) [6]. Other gas compounds such as $\mathrm{H}_{2} \mathrm{~S}$ may participate in the reactions which makes them rather complex, as shown in Eqs. (24) and (25) [66].

$$
\begin{gathered}
\mathrm{CH}_{2} \mathrm{CHCl}+2 \mathrm{H}_{2} \mathrm{O} \leftrightarrow 2 \mathrm{CO}+2 \mathrm{H}_{2}+\mathrm{HCl} \\
\mathrm{CH}_{4}+\mathrm{CO}_{2}+\mathrm{H}_{2} \mathrm{~S}+2 \mathrm{H}_{2} \mathrm{O} \leftrightarrow 2 \mathrm{CO}+5 \mathrm{H}_{2}+\mathrm{SO}_{2} \\
2 \mathrm{CH}_{4}+2 \mathrm{CO}_{2}+5 \mathrm{H}_{2} \mathrm{~S}+2 \mathrm{H}_{2} \mathrm{O}+2 \mathrm{O}_{2} \leftrightarrow 4 \mathrm{CO}+11 \mathrm{H}_{2}+5 \mathrm{SO}_{2}
\end{gathered}
$$


Fig. 15 The schematic of $\mathrm{SiO}_{4}$ tetrahedron structure and its relations with metal ions [128]

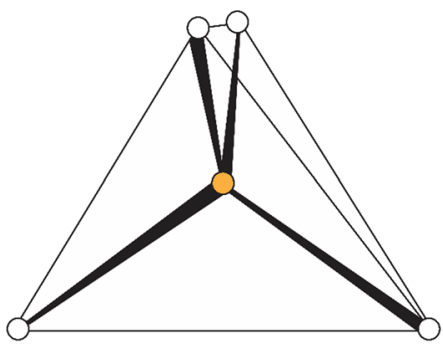

Oxygen atom

Silicon atom

Metal atom

Thermal plasma vitrification is suitable for inorganic hazardous waste such as fly ash since it confines hazardous substances such as heavy metals, preventing them from leaching. A limited number of studies on the vitrification of medical waste are available. However, plasma pyrolysis/gasification may include the vitrification process due to the existence of inorganic substances. Generally, heavy metals are trapped in the $\mathrm{SiO}_{4}$ tetrahedron inside the vitrified slag. This structure is the basic unit of all silicates as shown in Fig. 15, which chemically or physically traps metals. Different plasma process may obtain the solid product with different characteristics. For instance, in the plasma pyrolysis and gasification, slag is possible not to be formed or formed with a low hardness due to the lack of inorganic matters. Therefore, for some hazardous waste, glass formers such as $\mathrm{SiO}_{2}$ and $\mathrm{CaO}$ are needed to enhance the formation of vitrified slag [105, 124-127]. For feed continuation, the formed slag must be periodically tapped out of the furnace once the level is close to the maximum of the crucible.

\section{Conclusion}

The thermal plasma process provides a solution for treating medical waste of various composition, which can lead to a large reduction of the waste mass and volume, obtaining combustible gas and inert slag and destroying hazardous pathogens completely. In previous studies, various thermal plasma processes are applied to treat medical waste, such as plasma combustion, pyrolysis, gasification, and vitrification. Owing to the complex and changeable compositions of medical waste, the process should be well designed and the process parameters should be optimized for better treatment performance. Through the above analysis, including but is not limited to feed composition, feed rate, temperature, reactor environment, additives, etc., will influence the output of the treatment. Beyond doubt, thermal plasma treatment of medical waste is a promising alternative for eliminating risks of environment and human health in time, recovering energy and overcoming the difficulty of follow-up disposal. Besides, due to the characteristics of compact reactor geometry and lower pollutant emissions, the thermal plasma method may make sense for solving the problem of on-site treatment of medical waste, for example, when medical waste abnormally increases in a disease outbreak.

Acknowledgements This work was funded by the Zhejiang Natural Science Foundation of China (Grant Number LZ20F010001) and the National Natural Science Foundation of China (Grant Number 61871409).

Author Contributions CD developed the idea of the work, literature search and analysis were performed by $\mathrm{XC}$. The first draft of the manuscript was written by XC. CD provided critical review and substantially 
revised the manuscript and all authors commented on previous versions of the manuscript. All authors read and approved the final manuscript.

\section{Compliance with Ethical Standards}

Conflict of interest The authors declare that they have no conflict of interest.

\section{References}

1. Chartier Y, Emmanuel J, Pieper U et al (eds) (2014) Safe management of wastes from health-care activities: a practical guide, 2nd edn. Nonserial Publications, WHO Press, Geneva

2. Nema SK, Ganeshprasad KS (2002) Plasma pyrolysis of medical waste. Curr Sci 83(3):271-278

3. Komilis DP (2016) Issues on medical waste management research. Waste Manag 48:1-2. https:// doi.org/10.1016/j.wasman.2015.12.020

4. World Health Organization (2020) Health-care waste. https://www.who.int/en/news-room/factsheets/detail/health-care-waste. Accessed 10 Mar 2020

5. Fiedler J, Lietz E, Bendix D, Hebecker D (2004) Experimental and numerical investigations of a plasma reactor for the thermal destruction of medical waste using a model substance. J Phys D Appl Phys 37(7):1031. https://doi.org/10.1088/0022-3727/37/7/013

6. Huang J, Guo W, Xu P (2005) Thermodynamic study of water-steam plasma pyrolysis of medical waste for recovery of $\mathrm{CO}$ and $\mathrm{H}_{2}$. Plasma Sci Technol 7(6):3148. https://doi. org/10.1088/1009-0630/7/6/018

7. Rizan C, Mortimer F, Stancliffe R, Bhutta MF (2020) Plastics in healthcare: time for a re-evaluation. J R Soc Med 113(2):49-53. https://doi.org/10.1177/0141076819890554

8. Singh S, Prakash V (2007) Toxic environmental releases from medical waste incineration: a review. Environ Monit Assess 132(1):67-81. https://doi.org/10.1007/s10661-006-9503-3

9. Anastasiadou K, Christopoulos K, Mousios E, Gidarakos E (2012) Solidification/stabilization of fly and bottom ash from medical waste incineration facility. J Hazard Mater 207-208:165-170. https://doi.org/10.1016/j.jhazmat.2011.05.027

10. Chen Y, Zhao R, Xue J, Li J (2013) Generation and distribution of PAHs in the process of medical waste incineration. Waste Manag 33(5):1165-1173. https://doi.org/10.1016/j.wasman.2013.01.011

11. Windfeld ES, Brooks MS-L (2015) Medical waste management-a review. J Environ Manag 163:98-108. https://doi.org/10.1016/j.jenvman.2015.08.013

12. Fang S, Jiang L, Li P, Bai J, Chang C (2020) Study on pyrolysis products characteristics of medical waste and fractional condensation of the pyrolysis oil. Energy 195:116969. https://doi. org/10.1016/j.energy.2020.116969

13. Chen D, Yin L, Wang H, He P (2014) Pyrolysis technologies for municipal solid waste: a review. Waste Manag 34(12):2466-2486. https://doi.org/10.1016/j.wasman.2014.08.004

14. Basu P, Kaushal P (2009) Modeling of pyrolysis and gasification of biomass in fluidized beds: a review. Chem Prod Process Model. https://doi.org/10.2202/1934-2659.1338

15. Munir MT, Mardon I, Al-Zuhair S, Shawabkeh A, Saqib NU (2019) Plasma gasification of municipal solid waste for waste-to-value processing. Renew Sustain Energy 116:109461. https://doi. org/10.1016/j.rser.2019.109461

16. Zhukov MF, Zasypkina IM (2007) Thermal plasma torches: design, characteristics, application. Cambridge International Science Publishing, Cambridge

17. Rutberg PG, Lukyanov SA, Kiselev AA, Kuschev SA, Nakonechny GV, Nikonov AV, Popov SD, Serba EO, Spodobin VA, Surov AV (2011) Investigation of parameters of the three phase highvoltage alternating current plasma generator with power up to $100 \mathrm{~kW}$ working on steam. J Phys: Conf Ser 275:12006. https://doi.org/10.1088/1742-6596/275/1/012006

18. Surov AV, Popov SD, Popov VE, Subbotin DI, Serba EO, Spodobin VA, Nakonechny GV, Pavlov AV (2017) Multi-gas AC plasma torches for gasification of organic substances. Fuel 203:10071014. https://doi.org/10.1016/j.fuel.2017.02.104

19. Rutberg PG, Kuznetsov VA, Serba EO, Nakonechnyi GV, Nikonov AV, Popov SD, Surov AV (2013) Study of electric arcs in an air-steam mixture in AC plasma torches. High Temp 51(5):608614. https://doi.org/10.1134/S0018151X13050180 
20. Zhukovskii R, Chazelas C, Vardelle A, Rat V (2019) Control of the arc motion in DC plasma spray torch with a cascaded anode. J Therm Spray Technol 29(1-2):3-12. https://doi.org/10.1007/s1166 6-019-00969-8

21. Nemchinsky V (2016) A method to reduce electrode erosion in a magnetically driven rotating arc. IEEE Trans Plasma Sci 44(12):3474-3478. https://doi.org/10.1109/TPS.2016.2628885

22. Dave PN, Joshi AK (2010) Plasma pyrolysis and gasification of plastics waste - a review. J Sci Ind Res (India) 69:177-179

23. Tang L, Huang H, Zhao Z, Wu CZ, Chen Y (2003) Pyrolysis of polypropylene in a nitrogen plasma reactor. Ind Eng Chem Res 42(6):1145-1150. https://doi.org/10.1021/ie020469y

24. Huang H, Tang L (2009) Pyrolysis treatment of waste tire powder in a capacitively coupled RF plasma reactor. Energy Convers Manag 50(3):611-617. https://doi.org/10.1016/j.enconman.2008.10.023

25. Tang L, Huang H (2005) Thermal plasma pyrolysis of used tires for carbon black recovery. J Mater Sci 40(14):3817-3819. https://doi.org/10.1007/s10853-005-2552-0

26. Ibrahimoglu B, Demircan CA, Kizisar SE, Yilmazoglu MZ, Turkes N (2018) Energy recovery from waste tires with plasma method. In: 2nd international symposium on multidisciplinary studies and innovative technologies (ISMSIT), Ankara, Turkey, 19-21, October 2018. IEEE, pp 1-5. https://doi. org/10.1109/ismsit.2018.8567305

27. Rutberg PG, Bratsev AN, Kuznetsov VA, Popov VE, Ufimtsev AA, Shtengel' SV (2011) On efficiency of plasma gasification of wood residues. Biomass Bioenergy 35(1):495-504. https://doi. org/10.1016/j.biombioe.2010.09.010

28. Oost GV, Hrabovsky M, Kopecky V, Konrad M, Hlina M, Kavka T (2008) Pyrolysis/gasification of biomass for synthetic fuel production using a hybrid gas-water stabilized plasma torch. Vacuum 83(1):209-212. https://doi.org/10.1016/j.vacuum.2008.03.084

29. Hlina M, Hrabovsky M, Kavka T, Konrad M (2014) Production of high quality syngas from argon/ water plasma gasification of biomass and waste. Waste Manag 34(1):63-66. https://doi.org/10.1016/j. wasman.2013.09.018

30. Ruj B, Ghosh S (2014) Technological aspects for thermal plasma treatment of municipal solid waste-a review. Fuel Process Technol 126:298-308. https://doi.org/10.1016/j.fuproc.2014.05.011

31. Mazzoni L, Janajreh I (2017) Plasma gasification of municipal solid waste with variable content of plastic solid waste for enhanced energy recovery. Int J Hydrog Energy 42(30):19446-19457. https:// doi.org/10.1016/j.ijhydene.2017.06.069

32. Szałatkiewicz J (2016) Metals recovery from artificial ore in case of printed circuit boards, using plasmatron plasma reactor. Materials (Basel) 9(8):683. https://doi.org/10.3390/ma9080683

33. Rath SS, Nayak P, Mukherjee PS, Roy Chaudhury G, Mishra BK (2012) Treatment of electronic waste to recover metal values using thermal plasma coupled with acid leaching — a response surface modeling approach. Waste Manag 32(3):575-583. https://doi.org/10.1016/j.wasman.2011.11.001

34. Mitrasinovic A, Pershin L, Wen JZ, Mostaghimi J (2011) Recovery of Cu and valuable metals from e-waste using thermal plasma treatment. JOM 63(8):24-28

35. Zhao P, Ni G, Jiang Y, Chen L, Chen M, Meng Y (2010) Destruction of inorganic municipal solid waste incinerator fly ash in a DC arc plasma furnace. J Hazard Mater 181(1):580-585. https://doi. org/10.1016/j.jhazmat.2010.05.052

36. Ma W, Fang Y, Chen D, Chen G, Xu Y, Sheng H, Zhou Z (2017) Volatilization and leaching behavior of heavy metals in MSW incineration fly ash in a DC arc plasma furnace. Fuel 210:145-153. https:// doi.org/10.1016/j.fuel.2017.07.091

37. Yang S-F, Wang T-M, Lee W-C, Sun K-S, Tzeng C-C (2010) Man-made vitreous fiber produced from incinerator ash using the thermal plasma technique and application as reinforcement in concrete. $\mathrm{J}$ Hazard Mater 182(1):191-196. https://doi.org/10.1016/j.jhazmat.2010.06.014

38. Cheng TW, Chu JP, Tzeng CC, Chen YS (2002) Treatment and recycling of incinerated ash using thermal plasma technology. Waste Manag 22(5):485-490. https://doi.org/10.1016/S0956 $-053 \mathrm{X}(01) 00043-5$

39. Cheng TW, Huang MZ, Tzeng CC, Cheng KB, Ueng TH (2007) Production of coloured glass-ceramics from incinerator ash using thermal plasma technology. Chemosphere 68(10):1937-1945. https:// doi.org/10.1016/j.chemosphere.2007.02.046

40. Cubas ALV, de Machado MM, de Medeiros Machado M, Gross F, Magnago RF, Moecke EHS, Gonçalvez De Souza I (2014) Inertization of heavy metals present in galvanic sludge by DC thermal plasma. Environ Sci Technol 48(5):2853-2861. https://doi.org/10.1021/es404296x

41. Mountouris A, Voutsas E, Tassios D (2008) Plasma gasification of sewage sludge: process development and energy optimization. Energy Convers Manag 49(8):2264-2271. https://doi.org/10.1016/j. enconman.2008.01.025 
42. Celary P, Sobik-Szołtysek J (2014) Vitrification as an alternative to landfilling of tannery sewage sludge. Waste Manag 34(12):2520-2527. https://doi.org/10.1016/j.wasman.2014.08.022

43. Wang M, Mao M, Zhang M, Wen G, Yang Q, Su B, Ren Q (2019) Highly efficient treatment of textile dyeing sludge by $\mathrm{CO}_{2}$ thermal plasma gasification. Waste Manag 90:29-36. https://doi. org/10.1016/j.wasman.2019.04.025

44. Cai X, Wei X, Du C (2020) Thermal plasma treatment and co-processing of sludge for utilization of energy and material. Energy Fuels 34(7):7775-7805. https://doi.org/10.1021/acs.energyfuel s.0c00572

45. Fabry F, Rehmet C, Rohani V, Fulcheri L (2013) Waste gasification by thermal plasma: a review. Waste Biomass Valoriz 4(3):421-439. https://doi.org/10.1007/s12649-013-9201-7

46. Changming D, Chao S, Gong X, Ting W, Xiange W (2018) Plasma methods for metals recovery from metal-containing waste. Waste Manag 77:373-387. https://doi.org/10.1016/j.wasman.2018.04.026

47. Yu H, Sun X, Solvang WD, Zhao X (2020) Reverse logistics network design for effective management of medical waste in epidemic outbreak: insights from the coronavirus disease 2019 (COVID19) in Wuhan. SSRN J. https://doi.org/10.2139/ssrn.3538063

48. Taghipour H, Mohammadyarei T, Jafarabadi MA, Hashemi AA (2014) On-site or off-site treatment of medical waste: a challenge. J Environ Health Sci Eng 12:68. https://doi.org/10.1186/2052-336X-12-68

49. Jang Y-C, Lee C, Yoon O-S, Kim H (2006) Medical waste management in Korea. J Environ Manag 80(2):107-115. https://doi.org/10.1016/j.jenvman.2005.08.018

50. Liu B, Kikuchi M, Li H, Iwao T, Inaba T (2007) Dual torch plasma arc furnace for medical waste treatment. Plasma Sci Technol 9(6):709-712. https://doi.org/10.1088/1009-0630/9/6/16

51. Zhu HM, Yan JH, Jiang XG, Lai YE, Cen KF (2008) Study on pyrolysis of typical medical waste materials by using TG-FTIR analysis. J Hazard Mater 153(1):670-676. https://doi.org/10.1016/j. jhazmat.2007.09.011

52. Zroychikov NA, Fadeev SA, Bezruky PP (2018) Development of an environmentally safe process for medical waste disposal based on pyrolysis. Therm Eng 65(11):833-840. https://doi. org/10.1134/S0040601518110101

53. Petrov SV, Marynsky GS, Chernets AV et al (2020) Application of steam-plasma process for pyrolysis of organic, including medical and other hazardous wastes. http://plazer.com.ua/docs/pdf/ APPLICATION\%20OF\%20STEAM-PLASMA\%20PROCESS\%20.pdf. Accessed 11 Mar 2020

54. Heberlein J, Murphy AB (2008) Thermal plasma waste treatment. J Phys D Appl Phys 41(5):53001. https://doi.org/10.1088/0022-3727/41/5/053001

55. Han J, Kim H (2008) The reduction and control technology of tar during biomass gasification/pyrolysis: an overview. Renew Sustain Energy 12(2):397-416. https://doi.org/10.1016/j.rser.2006.07.015

56. Gray L (2014) Plasma gasification as a viable waste-to-energy treatment of municipal solid waste. In: MANE 6960-solid and hazardous waste prevention and control engineering, Hartford, CT, USA, pp 1-15. https://pdfs.semanticscholar.org/9815/d983a4155878b3fab18d313a931fd31ae4d5.pdf

57. Rutberg G, Bratsev AN, Safronov AA, Surov AV, Schegolev VV (2002) The technology and execution of plasmachemical disinfection of hazardous medical waste. IEEE Trans Plasma Sci 30(4):1445-1448. https://doi.org/10.1109/TPS.2002.804218

58. Park HS, Lee BJ, Kim SJ (2005) Medical waste treatment using plasma. J Ind Eng Chem 11(3):353-360

59. Anderson A, Morack M (2000) Plasma energy pyrolysis system (PEPS ${ }^{\mathrm{TM}}$ ) for destruction of industrial wastewater sludges. Proc Water Environ Fed 2000:214-235. https://doi.org/10.2175/19386 4700785156181

60. Sheng H, Wang R, Xu Y, Li Y, Tian J (2008) AC plasma arc system for pyrolysis of medical waste and pops. In: 27th annual international conference on thermal treatment technologies, Montreal, Quebec, Canada, pp 605-612. http://dspace.imech.ac.cn/handle/311007/60320

61. Li Y, Huang Z, Xu Y, Sheng H (2009) Plasma-arc technology for the thermal treatment of chemical wastes. Environ Eng Sci 26(4):731-737. https://doi.org/10.1089/ees.2008.0222

62. Sampathraju R, Mansuri MA (2019) Assessment of air pollutants in the occupational environment of plasma biomedical waste disposal system in Ahmedabad, India. J Environ Saf 10(2):89. https:// doi.org/10.11162/daikankyo.E19SC0601

63. Li J, Liu K, Yan S, Li Y, Han D (2016) Application of thermal plasma technology for the treatment of solid wastes in China: an overview. Waste Manag 58:260-269. https://doi.org/10.1016/j. wasman.2016.06.011

64. InEnTec (2020) PEM facilities. http://www.inentec.com/pem-facilities/. Accessed 1 July 2020

65. Achinas S (2020) An overview of the technological applicability of plasma gasification process. In: Singh P, Singh RP, Srivastava V (eds) Contemporary environmental issues and challenges in era of climate change. Springer, Singapore, pp 261-275. https://doi.org/10.1007/978-981-32-9595-7_15 
66. Zhovtyansky VA, Petrov SV, Lelyukh YI, Nevzglyad IO, Goncharuk YA (2013) Efficiency of renewable organic raw materials conversion using plasma technology. IEEE Trans Plasma Sci 41(12):3233-3239. https://doi.org/10.1109/TPS.2013.2275936

67. PEAT International (2020) PTDR-100 waste to energy system-Shanghai, China. http://www. peat.com/shanghai-china.html. Accessed 9 Mar 2020

68. Messerle VE, Mosse AL, Ustimenko AB (2018) Processing of biomedical waste in plasma gasifier. Waste Manag 79:791-799. https://doi.org/10.1016/j.wasman.2018.08.048

69. Ju Y, Sun W (2015) Plasma assisted combustion: dynamics and chemistry. Prog Energy Combust Sci 48:21-83. https://doi.org/10.1016/j.pecs.2014.12.002

70. Starikovskii AY (2005) Plasma supported combustion. Proc Combust Inst 30(2):2405-2417. https ://doi.org/10.1016/j.proci.2004.08.272

71. Starikovskiy A, Aleksandrov N (2013) Plasma-assisted ignition and combustion. Prog Energy Combust Sci 39(1):61-110. https://doi.org/10.1016/j.pecs.2012.05.003

72. Ju Y, Lefkowitz JK, Reuter CB, Won SH, Yang X, Yang S, Sun W, Jiang Z, Chen Q (2016) Plasma assisted low temperature combustion. Plasma Chem Plasma Process 36(1):85-105. https://doi. org/10.1007/s11090-015-9657-2

73. Lee CC, Huffman GL (1996) Medical waste management/incineration. J Hazard Mater 48(1-3):130. https://doi.org/10.1016/0304-3894(95)00153-0

74. Bacon M (2002) Plasma assisted sludge oxidation. Proc Water Environ Fed 2002:495-509. https:// doi.org/10.2175/193864702785302276

75. Mulhern T, Bacon M (2006) Full scale demonstration of plasma assisted sludge oxidation. Proc Water Environ Fed 2006(2):988-1001. https://doi.org/10.2175/193864706783796646

76. Punčochář M, Ruj B, Chatterj PK (2012) Development of process for disposal of plastic waste using plasma pyrolysis technology and option for energy recovery. Proc Eng 42:420-430. https:// doi.org/10.1016/j.proeng.2012.07.433

77. Goyal HB, Seal D, Saxena RC (2008) Bio-fuels from thermochemical conversion of renewable resources: a review. Renew Sustain Energy 12(2):504-517. https://doi.org/10.1016/j. rser.2006.07.014

78. Nachenius RW, Ronsse F, Venderbosch RH, Prins W (2013) Biomass pyrolysis. In: Murzin DY (ed) Chemical engineering for renewables conversion, Advances in Chemical Engineering, vol 42. Elsevier, Amsterdam, pp 75-139. https://doi.org/10.1016/b978-0-12-386505-2.00002-X

79. Miandad R, Barakat MA, Aburiazaiza AS, Rehan M, Nizami AS (2016) Catalytic pyrolysis of plastic waste: a review. Process Saf Environ Prot 102:822-838. https://doi.org/10.1016/j. psep.2016.06.022

80. Sharuddin SDA, Abnisa F, Daud WM, Wan A, Aroua MK (2016) A review on pyrolysis of plastic wastes. Energy Convers Manag 115:308-326. https://doi.org/10.1016/j.enconman.2016.02.037

81. Huang H, Tang L (2007) Treatment of organic waste using thermal plasma pyrolysis technology. Energy Convers Manag 48(4):1331-1337. https://doi.org/10.1016/j.enconman.2006.08.013

82. Solis M, Silveira S (2020) Technologies for chemical recycling of household plastics-a technical review and TRL assessment. Waste Manag 105:128-138. https://doi.org/10.1016/j.wasma n.2020.01.038

83. Fahmy TYA, Fahmy Y, Mobarak F, El-Sakhawy M, Abou-Zeid RE (2020) Biomass pyrolysis: past, present, and future. Environ Dev Sustain 22(1):17-32. https://doi.org/10.1007/s10668-018-0200-5

84. Janajreh I, Raza SS, Valmundsson AS (2013) Plasma gasification process: modeling, simulation and comparison with conventional air gasification. Energy Convers Manag 65:801-809. https:// doi.org/10.1016/j.enconman.2012.03.010

85. Byun Y, Cho M, Hwang S-M, Chung J (2012) Thermal plasma gasification of municipal solid waste (MSW). In: Yun Y (ed) Gasification for practical applications. InTech, London. https://doi. org/10.5772/48537

86. InEnTec (2020) PEM process details. http://www.inentec.com/pem-technology/process-details/. Accessed 3 July 2020

87. Zeng J, Yue Y, Gao Q, Zhang J, Zhou J, Pan Y, Qian G, Tang J, Ruan J (2019) Co-treatment of hazardous wastes by the thermal plasma to produce an effective catalyst. J Clean Prod 208:243251. https://doi.org/10.1016/j.jclepro.2018.10.069

88. Colombo P, Brusatin G, Bernardo E, Scarinci G (2003) Inertization and reuse of waste materials by vitrification and fabrication of glass-based products. Curr Opin Solid State Mater Sci 7(3):225239. https://doi.org/10.1016/j.cossms.2003.08.002

89. Chu JP, Hwang IJ, Tzeng CC, Kuo YY, Yu YJ (1998) Characterization of vitrified slag from mixed medical waste surrogates treated by a thermal plasma system. J Hazard Mater 58(1):179194. https://doi.org/10.1016/S0304-3894(97)00130-1 
90. Gomez E, Rani DA, Cheeseman CR, Deegan D, Wise M, Boccaccini AR (2009) Thermal plasma technology for the treatment of wastes: a critical review. J Hazard Mater 161(2-3):614-626. https:// doi.org/10.1016/j.jhazmat.2008.04.017

91. Paskalov G (2010) RF plasma system for medical waste treatment. US Patent 7,718,120, 18 May 2010

92. Caplan M, Bucher K, Tulupov A (2017) Hazardous and medical waste destruction using the AC plasmatron final report CRADA No. TC-1560-98. United States. https://doi.org/10.2172/1399747

93. Vaidyanathan A, Mulholland J, Ryu J, Smith MS, Circeo LJ (2007) Characterization of fuel gas products from the treatment of solid waste streams with a plasma arc torch. J Environ Manag 82(1):77-82. https://doi.org/10.1016/j.jenvman.2005.12.006

94. Fulcheri L, Fabry F, Takali S, Rohani V (2015) Three-phase AC arc plasma systems: a review. Plasma Chem Plasma Process 35(4):565-585. https://doi.org/10.1007/s11090-015-9619-8

95. Tang L, Huang H, Hao H, Zhao K (2013) Development of plasma pyrolysis/gasification systems for energy efficient and environmentally sound waste disposal. J Electrostat 71(5):839-847. https://doi. org/10.1016/j.elstat.2013.06.007

96. Gabbar H, Aboughaly M, Stoute CA (2017) DC thermal plasma design and utilization for the low density polyethylene to diesel oil pyrolysis reaction. Energies (Basel) 10(6):784. https://doi. org/10.3390/en10060784

97. Pan X, Yan J, Xie Z (2013) Detoxifying PCDD/Fs and heavy metals in fly ash from medical waste incinerators with a DC double arc plasma torch. J Environ Sci (China) 25(7):1362-1367. https://doi. org/10.1016/S1001-0742(12)60196-X

98. Sobiecka E, Cedzynska K, Smolinska B (2010) Vitrification as an alternative method of medical waste stabilization. Fresenius Environ Bull 19:3045-3048

99. Chernets OV, Korzhyk VM, Marynsky GS, Petrov SV, Zhovtyansky VA (2008) Electric arc steam plasma conversion of medicine waste and carbon containing materials. In: Jones JE (ed) 17th international conference on gas discharges and their applications, Cardiff, UK. IEEE, Piscataway, NJ, pp 465-468. https://ieeexplore.iee.xilesou.top/abstract/document/5379362

100. Beom KH, Hyung KW, Soo KB, Joon KH, Mingwei L, Chae Jae O (2007) Treatment of bone waste using thermal plasma technology. Plasma Sci Technol 9(5):616-618. https://doi. org/10.1088/1009-0630/9/5/21

101. Ministry of Ecology and Environment of the People's Republic of China (2007) Identification standards for hazardous wastes-identification for extraction toxicity (GB 5085.3-2007). http://engli sh.mee.gov.cn/Resources/standards/Solid_Waste/hazardousstandard/200710/t20071024_11194 6.shtml. Accessed 2 June 2020

102. U.S. Federal Government (2006) Identification and listing of hazardous waste. Code of Federal Regulation Part 261 Title 40. Office of the Federal Register, Washington, D.C. https://www.ecfr.gov/cgibin $/$ text-idx?SID =ce0006d66da40146b490084ca2816143\&mc $=$ true $\&$ node $=p t 40.26 .261 \& \operatorname{rgn}=\operatorname{div} 5 \#$ sp40.28.261.c. Accessed 2 June 2020

103. Zhang L, Yan J-H, Du C-M, Lu S-Y, Li X-D (2012) Study on vitrification of simulated medical wastes by thermal plasma. Huan Jing Ke Xue 33(6):2104-2109. https://doi.org/10.13227/j.hjkx.2012.06.050

104. Yugeswaran S, Ananthapadmanabhan PV, Kobayashi A, Lusvarghi L (2011) Transferred arc plasma processed mullite from coal ash and bauxite. Ceram Int 37(8):3437-3444. https://doi.org/10.1016/j. ceramint.2011.04.135

105. Sobiecka E, Szymanski L (2013) Thermal plasma vitrification process as an effective technology for fly ash and chromium-rich sewage sludge utilization. J Chem Technol Biotechnol 89(7):1115-1117. https://doi.org/10.1002/jctb.4221

106. Bień J, Celary P, Morzyk B, Sobik-Szołtysek J, Wystalska K (2013) Effect of additives on heavy metal immobilization during vitrification of tannery sewage sludge. Environ Prot Eng 39(2):33-40. https://doi.org/10.5277/EPE130204

107. Campbell LC (1992) Plasma pyrolysis of hazardous process and biological hospital waste. In: IEE colloquium on destruction of waste and toxic materials using electric discharges, London, UK. IET, 6/1-6/3. https://ieeexplore.ieee.org/document/214396

108. Li OL, Guo Y, Chang JS, Saito N (2015) Thermal plasma treatment of stormwater sediments: comparison between DC non-transferred and partially transferred arc plasma. Environ Technol 36(13):1672-1679. https://doi.org/10.1080/09593330.2014.1003981

109. Kim HI, Park DW (2004) Characteristics of fly ash/sludge slags vitrified by thermal plasma. J Ind Eng Chem 10(2):234-238

110. Cubas ALV, Machado M, Machado M, Moecke ES, Aguiar AR, Fiedler H, Bueno P (2016) Application of thermal plasma for inertization of sludge produced during treatment of landfill leachate. Quim Nova 39(8):906-913. https://doi.org/10.21577/0100-4042.20160135 
111. Scholtz V, Pazlarova J, Souskova H, Khun J, Julak J (2015) Nonthermal plasma-a tool for decontamination and disinfection. Biotechnol Adv 33(6 Pt 2):1108-1119. https://doi.org/10.1016/j.biote chadv.2015.01.002

112. Misra NN, Tiwari BK, Raghavarao KSMS, Cullen PJ (2011) Nonthermal plasma inactivation of foodborne pathogens. Food Eng Rev 3(3-4):159-170. https://doi.org/10.1007/s12393-011-9041-9

113. Moreau M, Orange N, Feuilloley MGJ (2008) Non-thermal plasma technologies: new tools for biodecontamination. Biotechnol Adv 26(6):610-617. https://doi.org/10.1016/j.biotechadv.2008.08.001

114. Liao X, Liu D, Xiang Q, Ahn J, Chen S, Ye X, Ding T (2017) Inactivation mechanisms of nonthermal plasma on microbes: a review. Food Control 75:83-91. https://doi.org/10.1016/j.foodc ont.2016.12.021

115. Sakudo A, Yagyu Y, Onodera T (2019) Disinfection and sterilization using plasma technology: fundamentals and future perspectives for biological applications. Int J Mol Sci. https://doi.org/10.3390/ ijms20205216

116. Tendler M, Rutberg P, van Oost G (2005) Plasma based waste treatment and energy production. Plasma Phys Control Fusion 47(2005):A219-A230. https://doi.org/10.1088/0741-3335/47/5A/016

117. Zhang L, Xu C, Champagne $\mathrm{P}$ (2010) Overview of recent advances in thermo-chemical conversion of biomass. Energy Convers Manag 51(5):969-982. https://doi.org/10.1016/j.enconman.2009.11.038

118. Arena U (2012) Process and technological aspects of municipal solid waste gasification. A review. Waste Manag 32(4):625-639. https://doi.org/10.1016/j.wasman.2011.09.025

119. Sun DL, Wang F, Hong RY, Xie CR (2016) Preparation of carbon black via arc discharge plasma enhanced by thermal pyrolysis. Diam Relat Mater 61:21-31. https://doi.org/10.1016/j.diamo nd.2015.11.004

120. Mohsenian S, Esmaili MS, Fathi J, Shokri B (2016) Hydrogen and carbon black nano-spheres production via thermal plasma pyrolysis of polymers. Int J Hydrog Energy 41(38):16656-16663. https:// doi.org/10.1016/j.ijhydene.2016.05.150

121. da Costa Labanca AR (2020) Carbon black and hydrogen production process analysis. Int J Hydrog Energy. https://doi.org/10.1016/j.ijhydene.2020.03.081

122. Ahmed I, Gupta AK (2009) Syngas yield during pyrolysis and steam gasification of paper. Appl Energy 86(9):1813-1821. https://doi.org/10.1016/j.apenergy.2009.01.025

123. Mountouris A, Voutsas E, Tassios D (2006) Solid waste plasma gasification: equilibrium model development and exergy analysis. Energy Convers Manag 47(13-14):1723-1737. https://doi.org/10.1016/j. enconman.2005.10.015

124. Tzeng C-C, Kuo Y-Y, Huang T-F, Lin D-L, Yu Y-J (1998) Treatment of radioactive wastes by plasma incineration and vitrification for final disposal. J Hazard Mater 58(1):207-220. https://doi. org/10.1016/S0304-3894(97)00132-5

125. Tu X, Wang Q, Yu L, Chéron B, Yan J, Cen K (2008) Diagnostic of novel atmospheric plasma source and its application to vitrification of waste incinerator fly ash. Energy Fuels 22(5):3057-3064. https:// doi.org/10.1021/ef800141b

126. Tu X, Yu L, Yan J, Cen K, Chéron BG (2010) Plasma vitrification of air pollution control residues from municipal solid-waste incineration. IEEE Trans Plasma Sci 38(12):3319-3325. https://doi. org/10.1109/TPS.2010.2056939

127. Wang Q, Yan J-H, Chi Y, Li X-D, Lu S-Y (2010) Application of thermal plasma to vitrify fly ash from municipal solid waste incinerators. Chemosphere 78(5):626-630. https://doi.org/10.1016/j. chemosphere.2009.10.035

128. Vogel W (2012) Glass chemistry, 2nd edn. Springer, Berlin

Publisher's Note Springer Nature remains neutral with regard to jurisdictional claims in published maps and institutional affiliations. 